San Jose State University

SJSU ScholarWorks

Master's Theses

Master's Theses and Graduate Research

Spring 2019

\title{
Pond Occupancy by Western Pond Turtles in the Diablo Range of Santa Clara County, California
}

Billy Tu

San Jose State University

Follow this and additional works at: https://scholarworks.sjsu.edu/etd_theses

\section{Recommended Citation}

Tu, Billy, "Pond Occupancy by Western Pond Turtles in the Diablo Range of Santa Clara County, California" (2019). Master's Theses. 5021.

DOI: https://doi.org/10.31979/etd.zr2k-wq38

https://scholarworks.sjsu.edu/etd_theses/5021

This Thesis is brought to you for free and open access by the Master's Theses and Graduate Research at SJSU ScholarWorks. It has been accepted for inclusion in Master's Theses by an authorized administrator of SJSU ScholarWorks. For more information, please contact scholarworks@sjsu.edu. 


\title{
POND OCCUPANCY BY WESTERN POND TURTLES IN THE DIABLO RANGE OF SANTA CLARA COUNTY, CALIFORNIA
}

\author{
A Thesis \\ Presented to \\ The Faculty of the Department of Environmental Studies \\ San José State University \\ In Partial Fulfillment \\ of the Requirements for the Degree \\ Master of Science
}

by

Billy Tu

May 2019 
(C) 2019

Billy Tu

ALL RIGHTS RESERVED 
The Designated Thesis Committee Approves the Thesis Titled

POND OCCUPANCY BY WESTERN POND TURTLES IN THE DIABLO RANGE OF SANTA CLARA COUNTY, CALIFORNIA

by

Billy Tu

APPROVED FOR THE DEPARTMENT OF ENVIRONMENTAL STUDIES

SAN JOSÉ STATE UNIVERSITY

May 2019

Lynne Trulio, Ph.D.

Department of Environmental Studies

Rachel O'Malley, Ph.D.

Department of Environmental Studies

Jessie Bushell, MS

Director of Conservation, San Francisco

Zoo 


\title{
ABSTRACT \\ POND OCCUPANCY BY WESTERN POND TURTLES IN THE DIABLO RANGE OF SANTA CLARA COUNTY, CALIFORNIA
}

\author{
by Billy Tu
}

The loss of natural habitat is one the primary drivers for species decline worldwide. Artificially, created habitat in human-altered landscapes can help supplement or enhance habitat for threatened wildlife populations. The western pond turtle (Emys pallida), a species declining in California, depends on aquatic habitats for its survival, but can use human-created livestock ponds in lieu of natural aquatic habits. This study examined the extent to which western pond turtle used livestock ponds in Santa Clara County, CA, and the importance of key habitat features in the turtle occupancy of livestock ponds. From March 2017 to September 2017, I conducted visual encounter surveys at 78 livestock ponds within the Diablo Range of eastern Santa Clara County. Habitat feature data were collected at 31 ponds. At each site, seven habitat features were evaluated: surface area, pond depth, elevation, number of basking structures, presence of bullfrogs, level of aquatic vegetation, and level of terrestrial tree and shrub cover. Evidence of turtles was found at 13 ponds. Habitat features did not statistically differ between occupied and nonoccupied sites, but the number of basking structures and tree and shrub cover may be biologically important. Of 16 previously documented sites, western pond turtles were extant at 12 and likely extant at two. One new documented site was recorded. These results indicate that ponds previously occupied are likely to still contain western pond turtles. To protect western pond turtles, conservation efforts should be directed towards protecting known sites and restoring previously occupied sites. 


\section{ACKNOWLEDGMENTS}

The journey to completing this thesis has been a long time coming and would not have been possible without the support and guidance received from my committee, mentors, friends, collaborators, and funders. First, I would like to thank Dr. Lynne Trulio for her continued support throughout this entire process. To my committee members, Dr. Rachel O'Malley and Jessie Bushell, thank you for your guidance and show of support.

Secondly, I am grateful for my fiancée, Yen Tran, for sticking by me while I pursued my passion for turtles. To my field assistants (Alec Irwin, Carole Foster, Elisabeth Wilkinson, Emily Moffitt, Huy Vuong, Jim Buskirk, Kendra Mann, Lynea Baudino, Sami Boutros, Sinzee Tran, \& Yen Tran), there is no one I would rather spend an afternoon covered in ticks with than you - thank you for your hard work. Much appreciation to the staff at Blue Oak Ranch Reserve, Santa Clara County Parks, San Felipe Ranch, Santa Clara Valley Water District, and Henry Coe State Park for allowing me access and/or shuttling me to my research sites. Dr. Shannon Bros provided much needed statistical analysis advice, while Nicole Catalano help edited this paper. Elisabeth Wilkinson, Mark Seelos, and Colin Kortman helped with GIS.

Lastly, I would not have been financially able to complete my thesis and degree without the support from the College of Social Science RSCA grants, Mary Bowerman Science and Research Grant, Mid-Atlantic Turtle \& Tortoise Society, San Francisco Zoo Conservation Department, and the John Luckhardt-Kiwanis Memorial Scholarship and the Tricia and Pete Biocini Scholarship Fund, both in the Department of Environmental Studies. 


\section{TABLE OF CONTENTS}

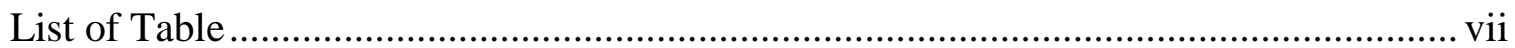

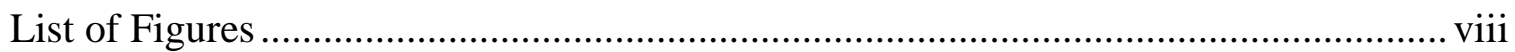

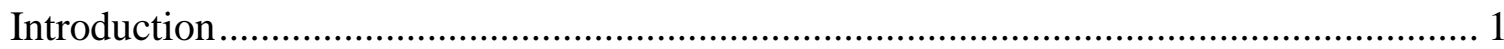

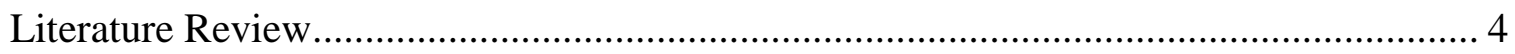

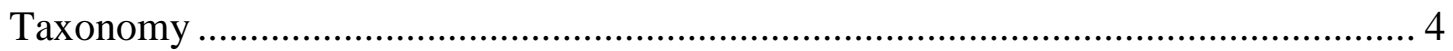

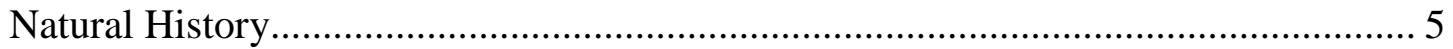

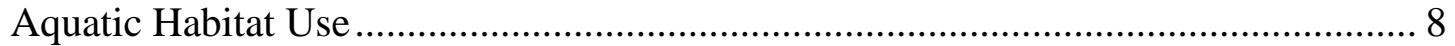

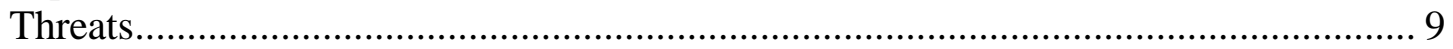

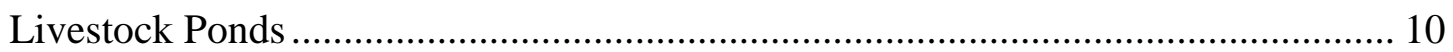

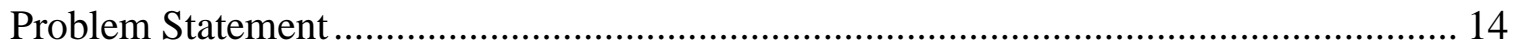

Research Questions and Hypothesis .......................................................................... 15

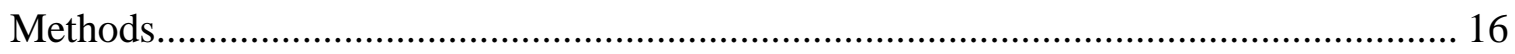

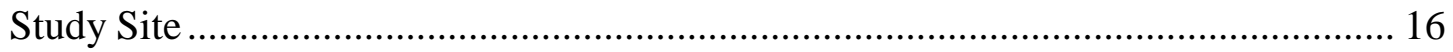

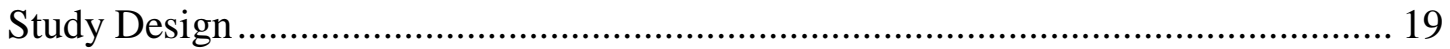

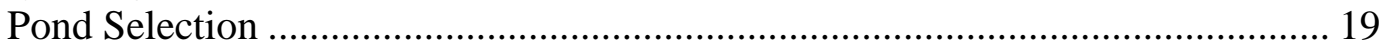

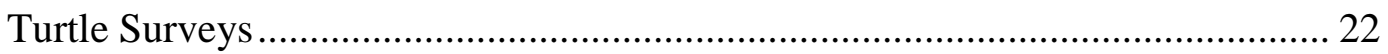



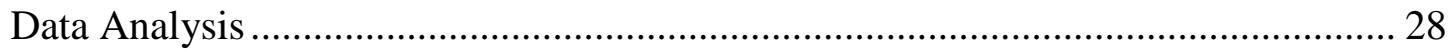

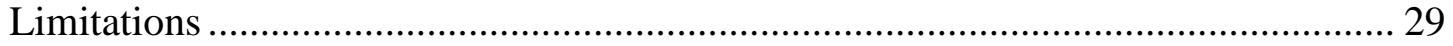

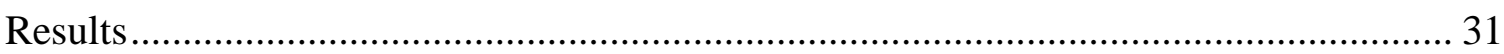

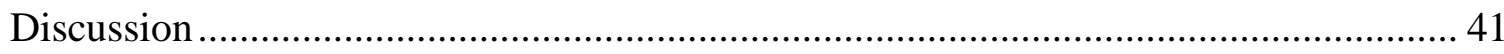

Livestock Ponds Usage by Western Pond Turtle....................................................... 41

Livestock Ponds and Habitat Features .................................................................... 42

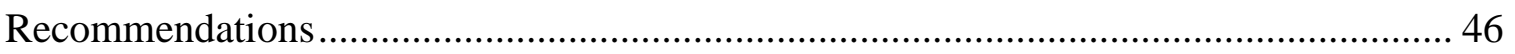

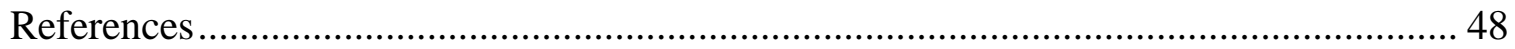




\section{LIST OF TABLES}

Table 1. Current Land Use and Size of the Five Study Sites: Rancho Canada de Pala Reserve, Blue Oak Ranch Reserve, Joseph Grant County Park, San Felipe Ranch, and Henry Coe State Park

Table 2. Ponds Surveyed and Data Collection Sites

Table 3. Previously Documented Occurrence vs. Survey Results (78 Total Ponds)

Table 4. Lakes Surveyed

Table 5. Range, Mean, Standard Deviation (SD) and MANOVA Results for Pond Occupancy

Table 6. Pearson Chi-Square Analysis and Likelihood Ratio for Pond Occupancy.... 


\section{LIST OF FIGURES}

Figure 1. Map of the Five Study Sites in Santa Clara County, California: Rancho Canada de Pala Reserve, Blue Oak Ranch Reserve, Joseph Grant County Park, San Felipe Ranch, and Henry Coe State Park........

Figure 2. Livestock Pond at Joseph Grant County Park

Figure 3. Western Pond Turtles observed at San Felipe Ranch

Figure 4. Tree and Shrub Cover Polygon .................................................... 28

Figure 5. Ponds and Lakes Surveyed ...................................................... 34

Figure 6. Habitat Data Collection Sites .................................................. 35

Figure 7. Number of Basking Structures Power Curve Analysis ....................... 37

Figure 8. Emergent Vegetation Comparison Between Ponds with and without Western Pond Turtle

Figure 9. Submersed Vegetation Comparison Between Ponds with and without Western Pond Turtle

Figure 10. Presence of Bullfrogs Comparison Between Ponds with and without Western Pond Turtle

Figure 11. Tree and Shrub Cover Between Ponds with and without Western Pond Turtles 


\section{Introduction}

The human population has grown exponentially in recent decades, reaching 7.4 billion people in 2017. With this growth, the resources needed to support the human population have increased dramatically, putting more pressure on the finite resources available to other species. Human activities are estimated to have increased the rate of animal extinction to more than one thousand times the natural level (Ceballos, García, \& Ehrlich, 2010). The current rate of species loss is so extreme that scientists are comparing this phenomenon to previous mass extinctions, where more than $75 \%$ of all species were lost in each extinction event alone (Barnosky et al., 2011; Wake \& Vredenburg, 2008). This current species extinction event is the result of anthropogenic activities that influence global climate change, spread non-native species, pathogens and toxins, overharvest resources, destroy and fragment habitats, and overhunt species (Barnosky et al., 2011).

The Order Testudine (formally Chelonia), commonly referred to as chelonians, comprised of turtles, terrapins, and tortoises, is experiencing dramatic declines. Of the roughly 350 chelonian species in the world, more than half are threatened with extinction (Turtle Conservation Coalition, 2018). The primary threats to chelonians are habitat loss from urban and agricultural developments, pollution, over-collection for consumption and traditional medicine, and the legal and illegal pet trade (Turtle Conservation Coalition, 2018). Chelonians are particularly vulnerable to extirpation because of their life history characteristics. Most chelonians have a slow growth rate, delayed sexual maturity (typically between 10-15 years), high fecundity combined with low juvenile 
survival and high adult survival rate (Turtle Conservation Coalition, 2011). Thus, even a small decline in adult numbers can greatly reduce local turtle populations.

One chelonian species gaining attention because of recent declines is the western pond turtle (WPT) (Emys marmorata and Emys pallida). Western pond turtles are found along the western region of the United States from Puget Sound, Washington to Baja California. Once considered widespread throughout its range, WPT populations have dropped considerably and are now considered Endangered in Washington, Critical in Oregon, and a Species of Special Concern in California. The primary threats to the survival of WPTs are habitat alteration, destruction, and fragmentation (Bury \& Germano 2008; Cook \& Martini-Lamb, 2004).

In Santa Clara County (the County), California, the human population has risen steadily over the past 50 years, from roughly 640,000 individuals in 1960 to over 1.7 million by 2010 (Bay Area Census, 2010) and this growth has been accompanied by extensive urban growth and suburban sprawl. Housing, businesses, roads and other urban elements have completely transformed the landscape and habitats of the region. Urban development has been concentrated on the Santa Clara County valley floor, an area known worldwide as Silicon Valley, but this area historically provided habitat for a great variety of flora and fauna, including WPTs. As development continues to encroach upon and alter the remaining natural landscape in the County, wildlife managers must identify where WPT populations persist, evaluate the habitats that help support a viable turtle population, and identify management actions that can protect the species. 
In the Diablo Range of Eastern Santa Clara County, cattle grazing has helped preserve some natural habitats, including oak woodlands, riparian forest, and seasonal and permanent waterways, from urban development. Cattle grazing has also altered grassland habitat which includes providing many livestock ponds to support the cattle. These ponds can benefit species such as the WPT. In fact, WPT have been found in abundance in stock ponds and other standing water bodies created by humans (Bury \& Germano, 2008). Although the extent of livestock pond usage by WPT is unknown, these ponds may be important features in the conservation and management of WPT populations.

Managing western pond turtles for persistent populations is hampered by a lack of basic information, such as where WPTs are located, the habitat features they prefer, and the extent to which human-altered landscapes, such as grazed lands, can support this species. To improve our understanding of WPT habitat requirements, this study surveyed livestock ponds in the Diablo Range of Santa Clara County to determine the extent of their occupation by WPT and to evaluate the relationships among key habitat features and WPT occupancy. 


\section{Literature Review}

\section{Taxonomy}

The western pond turtle (Emys marmorata and Emys pallida, formerly Clemmys marmorata) was first described by Baird \& Girard in 1852 from a specimen collected from Fort Steilacoom in Western Washington (Bury, Jr, Germano, \& Ashton, 2012). Originally named Emys marmorata by Baird \& Girard (1852), the WPT was first referred to as Actinemys marmorata by Baird in 1858 (Bury et al., 2012). In 1862, Strauch referred to the WPT as Clemmys marmorata, which became the standard name for more than a century. More recent analysis has suggested that the WPT be assigned back to the genus Emys, but Feldman \& Parham (2002) have argued that the genus is paraphyletic and recommend that the WPT be put into its own genus, Actinemys.

Seeliger (1945) first proposed two separate subspecies of WPT based on coloration and the presence and shape of the inguinal scute. The northern population was considered the Northwestern Pond Turtle (C. m. marmorata) and the southern population the Southwestern Pond Turtle (C. m. pallida), with the divide occurring near the American River in Central California. Spinks \& Shaffer (2005) identified further variation in the species suggesting four distinct clades across the turtles' range. A large clade was suggested to occupy the area from San Luis Obispo County (SLO) to Puget Sound, WA. The remaining three clades occur south of SLO and are highly varied, requiring additional evidence to support their distinction. Using a greater sample size and number of genetic markers, Spinks et al. (2014) recently recommended splitting the WPT into two, and possibly three, separate species, Emys marmorata and Emys pallida, with 
the divide occurring in the San Francisco Bay. This distinction is currently recognized by the California Department of Fish and Wildlife (CDFW) and the United States Fish and Wildlife Service (USFWS).

\section{Natural History}

Although primarily aquatic, WPTs spend a considerable amount of time on land and travel great distances to search for food, overwintering and estivating sites and to find new water bodies when their water source dries up (Bury et al., 2012; Reese \& Welsh, 1997; Zaragoza, Rose, Purcell, \& Todd, 2015). In an ephemeral pond along the Sierra Nevada foothills, Zaragoza et al. (2015) estimated that WPTs spend an average of 235 days per year on land during periods of below-average precipitation. As the pond began to dry, the turtles migrated out to estivate in nearby leaf litter before returning during the heavy rainfall. Reese and Welsh (1997) found that WPTs were willing to travel as far as $500 \mathrm{~m}$ from their aquatic habitat in the Trinity River to overwinter. Research on the home range of WPT by Bury (1972) in Northern California found that adult males travel much further than females and juveniles. Holland (1994) found WPT movements occurring throughout the day with $63 \%$ of monitored turtles displaying nocturnal movements, while $72 \%$ of turtles moved during the day.

Activities patterns, such as timing of mating and overwintering, are highly dependent on temperatures. In relatively warm areas, such as in Southern California, turtles emerge from overwintering sites as early as February (Holland, 1994). Most turtles overwinter underwater or under various terrestrial substrates, starting in September or October, and emerge between March and May (Bury et al., 2012). Typically, when surface water 
temperatures are at or above $15^{\circ} \mathrm{C}$, turtles become more visible (Buskirk, 2002). The nesting season normally begins in early May and lasts until July. Copulation occurs primarily underwater, and most gravid female turtles will nest within $50 \mathrm{~m}$ from the water's edges. Nesting distances as great as $400 \mathrm{~m}$ have also been documented (Holland, 1994; Reese \& Welsh, 1997).

Nesting habitats are characterized by short vegetation, such as grass and shrubs, which provide direct sunlight to the nest, and containing high silt or clay content (Rathbun, Siepel, \& Holland, 1992; Rathbun, Scott Jr, \& Murphey, 2002). In some instances, female WPT may exhibit nest site fidelity. One radio-tagged female in the Willamette Valley, Oregon, reused the same nest site for five consecutive years (Bury et al., 2012). Females dig nests with their back legs and deposit between two and thirteen eggs (Bury et al., 2012). After the eggs are laid the female turtle covers the nest and returns to the water. In most cases, gravid female turtles lay only one clutch per season, but two and three clutches have been documented (Bury \& Germano, 2008; Lovich \& Meyer, 2002; Pires, 2001). In the wild, eggs are incubated in the ground for 94 to 122 or more days (Holland, 1994). Most hatchlings will overwinter in the nest chamber, but spatial temperature differences throughout the WPT range, particularly in warm winter areas such as Southern California, may cause some hatchlings to emerge early from the nest. Additional research is needed to determine the range and extent of early nest emergence amongst hatchlings WPT.

The growth rate of WPTs is highly dependent on temperature and food resources but, in general, growth is greatest during their first few years after emergence from nest. 
During their first year, hatchlings turtles are estimated to grow between 3.3 to $6.1 \mathrm{~mm}$ per month (Buskirk, 2002; Reese, 1996). By their fourth year, the rate decreases to $1.3 \mathrm{~mm}$ per month in Northern California (Reese, 1996). Neonates are on average 24 to $32 \mathrm{~mm}$ long (carapace length) and weigh between 3 and 7 grams (Bury et al., 2012). As adults, the turtles can reach $240 \mathrm{~mm}$ and weigh upwards of 1200 grams. While the maximum life span of the WPT is unknown, Bury et al. (2012) recorded a specimen believed to be over 50 years old based on recapture data. Reproductive females can start reproducing when they are four years old, although their sexual maturity is often based on size and location (Bury et al., 2012; Germano \& Rathbun, 2008). On average, males reach sexual maturity between five and nine years old, and females mature between seven and ten years old (Bury \& Germano, 2008).

Incubation temperatures determine the sex of many reptiles, including turtles and tortoises. In a temperature-controlled experiment, Geist, Dallara, \& Gordon (2015) determined the WPT pivotal temperature, i.e., the temperature where the male-female sex ratio is $1: 1$, to be $29.4^{\circ} \mathrm{C}$. Temperatures above the pivotal temperature would be skewed for fewer males to females, and vice versa. Further research is needed to investigate the impacts of natural temperature fluctuations on the sex ratio and hatchling success of wild WPT (Geist et al., 2015).

Western pond turtles are opportunistic omnivores, feeding primarily on aquatic invertebrates and vegetation. Stomach contents of 77 WPTs from Northern California included a variety of aquatic insects comprising mostly Ephemeroptera nymphs, Trichoptera larvae, Diptera larvae, and Odonata nymphs (Bury, 1986). Food items also 
included small vertebrates, such as fish, frogs, crustaceans and tadpoles, as well as carrion. Aquatic vegetation such as pond lilies, tule roots, and filamentous algae are also occasionally consumed. As hatchlings, WPT feed mainly on insects before consuming more plant matter as adults (Bury et al., 2012).

\section{Aquatic Habitat Use}

Western pond turtles are cryptic semiaquatic turtles that inhabit a variety of freshwater bodies. They have been documented residing in natural and human-altered freshwater bodies such as creeks, rivers, reservoirs, canals, estuaries, natural ponds, cattle ponds, wastewater effluent ponds, marshes, and lakes (Bury \& Germano, 2008; Buskirk, 2002; Cook \& Martini-Lamb, 2004; Lambert, Nielsen, Wright, Thomson, \& Shaffer, 2013; Spinks, Pauly, Crayon, \& Shaffer, 2003). These water bodies are diverse and may be characterized as lentic or lotic systems with permanent or ephemeral water characteristics. While WPT exhibit some habitat flexibility, they prefer standing or slowflowing systems with underwater refugia and basking habitat (Bury \& Germano, 2008). For example, Bury (1972) found that most WPTs along a $3.5 \mathrm{~km}$ stretch of stream were living in pools as opposed to shallow riffle sections. Reese \& Welsh (1998) found similar results in dammed and free flowing sections of the Trinity River in northern California, although they found the presence of basking structures were a better predictor of WPT presence. Basking structures are vital habitat features, because they provide the necessary means for atmospheric thermoregulation, thereby allowing metabolic processes to continue when body temperature is increased. Proper digestion of food provides energy for growth and reproduction and optimizes behaviors associated with feeding and 
predator evading (Bodie, 2001; Dubois, Blouin-Demers, Shipley, \& Thomas, 2009). A variety of basking structures have been documented for WPT including exposed logs, emergent vegetation, rocks, mud banks, and concrete substrate (Bury \& Germano, 2008; Cook \& Martini-Lamb, 2004; Lambert et al., 2013).

\section{Threats}

Western pond turtle populations are in decline throughout their range (Spinks et al., 2003). Areas believed to be the most significantly impacted include the Central Valley of California, Southern California from Ventura down to Baja, and the northernmost populations in Washington, where it is currently listed as Endangered (Bury \& Germano, 2008; Jennings \& Hayes, 1994). A survey of 55 sites by Germano \& Bury (2001) in California's Central Valley found 15 sites with turtles present, of which five were believed to support viable populations. Very few reproducing populations are known in the Southern California range (Spinks et al., 2014). Out of 255 sites inspected in 1987, 53 contained WPTs (Lovich, 1998). Of the 53, only 10 sites were thought to contain suitable habitat.

In California, the WPT is currently listed as a Species of Special Concern. However, due to the new taxonomic split recommended by Spinks et al. (2014), the turtles could be placed in a status such as threatened or endangered. In 2012, the Center for Biological Diversity petitioned for the WPT to be listed under the Federal Endangered Species Act (Center for Biological Diversity, 2012). Its status is currently under review.

Primary threats to the survival of WPTs in California are habitat alteration, destruction and fragmentation (Bury \& Germano, 2008; Cook \& Martini-Lamb, 2004). 
Urban and agricultural development in California's Central Valley and Southern region have resulted in marked declined and extirpation of many populations (Bury \& Germano, 2008; Germano \& Bury, 2001; Holland, 1991; Rathbun et al., 1992). Water development projects, such as dams and canals, and drainage of wetlands have altered and fragmented suitable WPT habitat. For example, water levels in reservoirs can fluctuate seasonally, which inhibit the growth of aquatic, riparian vegetation and the associated invertebrates that the turtles' prey on. Water temperatures downstream of reservoirs are also reduced, because water is often released at the hypolimnion. Reese \& Welsh (1998) found water downstream of dams had cooler water temperatures and higher velocity, which can be detrimental to turtles due to their thermal requirements. Recreational activities such as boating and fishing in reservoirs can also make habitat unsuitable for turtles, as WPT are easily disturbed by human activities (Bury \& Germano, 2008).

Negative impacts caused by non-native invasive species also contribute to the decline of the WPT population. Invasive species, such as the bullfrog (Lithobates catesbeianus) and largemouth bass (Micropterus spp.), are known to predate on hatchlings and small juvenile turtles (Holland, 1991). Even plant species such as Tamarisk (Tamarix ramosissima) can indirectly impact WPT survival by altering habitat hydrology and morphology and increasing sediment accumulation (Lovich \& de Gouvenain., 1998). Predation of eggs by non-native feral pigs has also been documented (Wilcox, 2010). Although few empirical data are available, Spinks et al. (2003) postulate that there may be competition between WPTs and non-native turtles, particularly red-ear sliders (Trachemys scripta), for basking sites and food resources. 


\section{Livestock Ponds}

Livestock (stock) ponds are human-created features, found in grazed lands throughout the dry regions of the western United States. They are often built along low-ordered tributaries, which drain from nearby hill-slopes, to support grazing and/or agricultural activities (Florsheim, Chin, \& Nichols, 2013). Small dams were built to retain water, but as a result they often disrupt the natural flow of water, nutrients, and sediments. Water velocity decreases as it enters the pond, increasing its residence time and allowing water temperatures to rise (Poff \& Hart, 2002). Coarse sediments and nutrients that normally would flow downstream become trapped behind the dam, decreasing the pond's depth and causing it to eutrophy over time. Lower water depth allows more sunlight to penetrate and increases water temperatures, leading to proliferation of algae and changes in wetland vegetation communities from lotic to lentic species (Florsheim et al., 2013). Without proper maintenance, natural succession will eventually transform an open water pond into a shallow marsh or meadow.

Despite these temporal changes, stock ponds are considered high value conservation areas because they contribute significantly to regional biodiversity and help support endangered species (Declerck et al., 2006; Ruggiero, Céréghino, Figuerola, Marty, \& Angélibert, 2008; Usio et al., 2013). Species benefit from stocks ponds because they provide alternative habitat when natural habitat has disappeared (Casa et al., 2012), and they can enhance preexisting habitat. Knutson et al. (2004) concluded that if small stock ponds were managed properly, they could help sustain amphibian populations in areas where natural wetlands are uncommon. Artificially-created habitat can essentially help 
supplement habitat for wildlife populations that are facing decline due to habitat loss. In California, threatened species such as the Diablo Range gartersnake (Thamnophis atratus zaxanthus), California tiger salamander (Ambystoma californiense), California red legged frogs (Rana draytonii), and western pond turtles are known to inhabit stock ponds and can potentially benefit from the development of additional stock ponds. More common species, including Pacific tree frog (Hyla regilla) and western toad (Bufo boreas), also make use of stock pond habitat.

Management of ponds in grazed areas to support native species is needed to allow cattle and wildlife to coexist. Active cattle grazing in and around stock ponds can reduce WPT survival by polluting the water and destroying beneficial habitat features, such as bank-side vegetation used for foraging. High stocking densities of cattle can lead to excess nitrate and sulfate concentrations in the water via feces and urine runoff (Fidenci, 2000). Grazing of aquatic vegetation, particularly along pond banks, can be harm WPT because vegetation serves as habitat for hatchling turtles and food sources (aquatic insects), and as basking sites (Fidenci, 2000; Hays, McAllister, Richardson, \& Stinson, 1999). Direct trampling of turtles can also occur along the pond's shoreline.

\section{Western Pond Turtles in Santa Clara County, CA}

Western pond turtles can be found in a variety of aquatic habitats in Santa Clara County, CA, including reservoirs, percolation ponds, rivers, lakes, and permanent and intermittent creeks and ponds (CNDDB, 2018, H.T. Harvey \& Associates, 1999, 2012; Leidy, Bogan, Neuhaus, Rosetti, \& Carlson, 2016; Nyhof \& Trulio, 2015). In more lowland areas, where urban development is high, WPTs are generally less likely to be 
found, possibly due to a lack of dispersal corridors and open upland habitat adjacent to the sites. Nonetheless, WPT have been documented in semi-urban reaches of Guadalupe, Coyote, and San Francisquito Creeks and in several human-altered lentic waterbodies (freshwater canals and percolation ponds) (H.T. Harvey \& Associates, 1999, 2012). At higher elevation areas, such as the foothills of the Diablo and Santa Cruz mountain ranges, where there is less urban development, WPT can be found in larger water bodies such as Vasona, Anderson, and Chestbro Reservoir, as well as in more natural, permanent and intermittent ponds and creeks (CNDDB, 2018, H.T. Harvey \& Associates, 1999, 2012; Leidy et al. 2016). 


\section{Problem Statement}

The destruction of natural habitat is one of the primary drivers of species loss worldwide (Barnosky et al., 2011; Ceballos, García, \& Ehrlich, 2010; Wake \& Vredenburg, 2008). In Santa Clara County, CA, urban development has permanently altered the natural landscapes that once supported a variety of native flora and fauna, including western pond turtles. In the Diablo Range of Eastern Santa Clara County, however, land used for cattle grazing has helped preserve many natural features and habitat areas for native wildlife. Grazing has resulted in the creation of hundreds of livestock ponds that have benefitted sensitive species such as the western pond turtle. Little is known regarding the extent to which stock ponds may be inhabited by WPT in the County and few studies have examined the habitat features that may attract pond turtles to lentic systems, such as stock ponds. This study helps fill this information gap by providing data on the extent to which stock ponds are occupied by WPT and by identifying habitat features that support WPT in stock pond habitat. 


\section{Research Questions and Hypothesis}

1. To what extent were livestock (stock) ponds occupied by western pond turtles in the Diablo Range of Santa Clara County, CA, in $2017 ?$

a. What percent of stock ponds were occupied by WPT in 2017 ?

b. What percent of stock ponds, with no records of WPT occupancy, were occupied by WPT in 2017 ?

c. How does the number of occupied stock ponds, in 2017, compare with previously documented occurrences?

$\mathrm{HO}_{1}$ : Stock ponds occupied by WPT in the Diablo Range of Santa Clara County do not differ in maximum pond surface area, maximum water depth, elevation, number of basking structures, aquatic vegetation (submersed and emergent) cover, presence of bullfrogs, and tree and shrub cover compared to stocks ponds without WPT. 


\section{Methods}

\section{Study Site}

This study was conducted within the Diablo Range of eastern Santa Clara County, California (Figure 1). Mount Hamilton is the highest summit in the study area, at approximately $1300 \mathrm{~m}$ above sea level, and is located on the eastern side of the County $\left(37^{\circ} 20^{\prime} 30.2^{\prime \prime} \mathrm{N}, 121^{\circ} 38^{\prime} 34.2^{\prime \prime} \mathrm{W}\right)$. The County has a Mediterranean-type climate characterized by cool and wet winters, while the summers are warm and dry. The average low and high temperatures in January, the coldest month of the year, are $2.7^{\circ} \mathrm{C}$ and $9.2^{\circ} \mathrm{C}$, and $17.4^{\circ} \mathrm{C}$ and $25.9^{\circ} \mathrm{C}$ in July, the warmest month (Western Regional

Climate Center, 2016). Average annual precipitation is approximately $60 \mathrm{~cm}$ and snow may appear when conditions are optimal. 


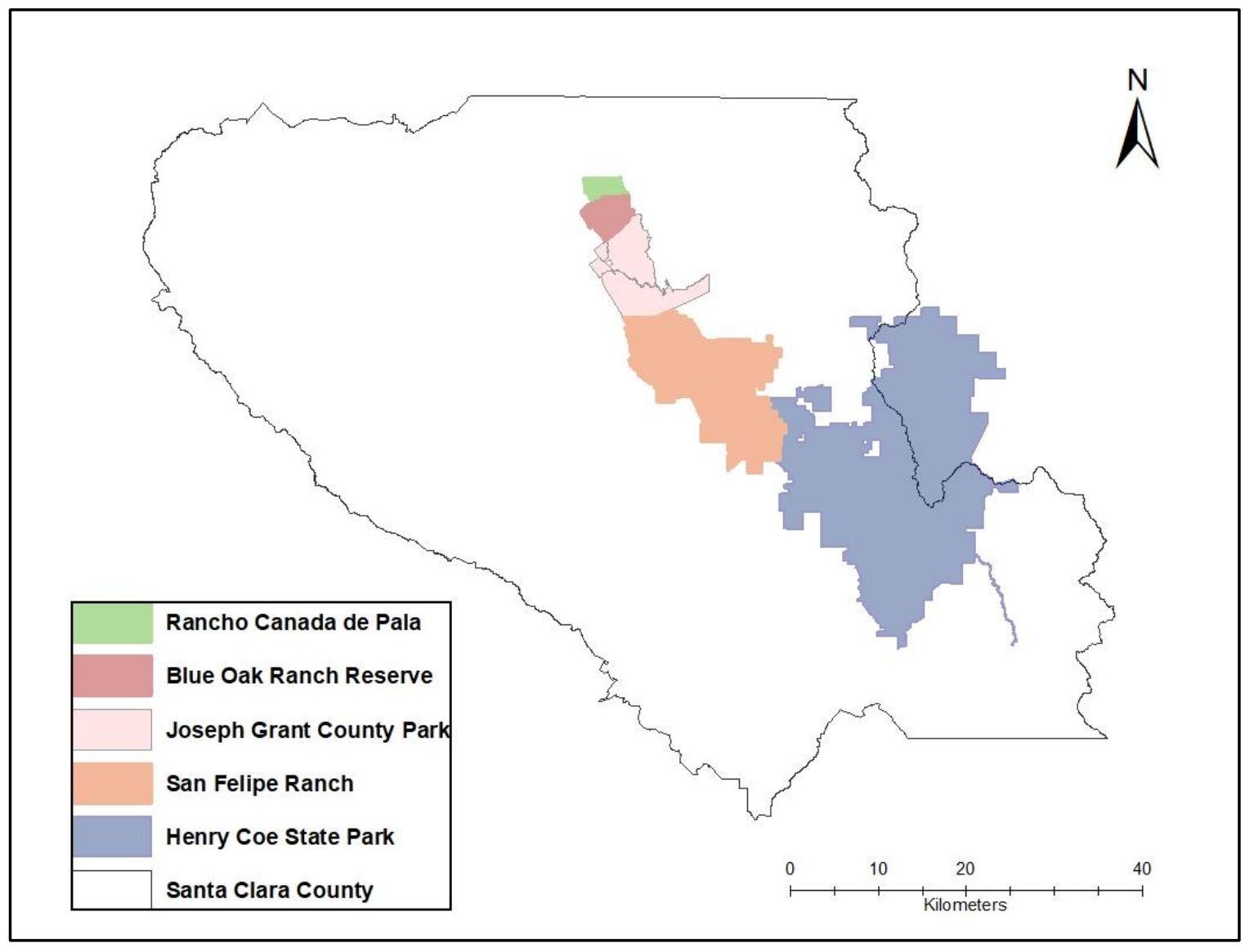

Figure 1. Map of the Five Study Sites in Santa Clara County, California: Rancho Canada de Pala Reserve, Blue Oak Ranch Reserve, Joseph Grant County Park, San Felipe Ranch, and Henry Coe State Park.

Specifically, the study was conducted on five properties (Figure 1) owned by the University of California Natural Reserve System (Blue Oak Ranch Reserve, BORR), Santa Clara County Parks (Joseph Grant County Park, JGCP), Hewitt Packard Family (San Felipe Ranch, SFR), Santa Clara Valley Water District (Rancho Canada de Pala, RCDP), and California State Parks (Henry Coe State Park, HCSP). The combined size of all five properties was over 53,000 ha (Table 1). Beginning in 1998, The Nature Conservancy's Mount Hamilton Project worked to preserve "the last significant expanse 
of open space between San Francisco and the Great Central Valley" by acquiring land and partnering with local landowners (The Nature Conservancy, 2018). Conservation easements were established at BORR, RCDP, and SFR, which link the three properties with JGCP and HCSP, thereby protecting a large continuous area from future development.

Table 1.

Current Land Use and Size of the Five Study Sites: Rancho Canada de Pala Reserve, Blue Oak Ranch Reserve, Joseph Grant County Park, San Felipe Ranch, and Henry Coe State Park.

\begin{tabular}{|l|c|c|l|}
\hline \multicolumn{1}{|c|}{ Property } & Acronyms & Acres & \multicolumn{1}{c|}{ Land Use } \\
\hline $\begin{array}{l}\text { Rancho Canada de Pala } \\
\text { Reserve }\end{array}$ & RCDP & 711 & Private Reserve \\
\hline Blue Oak Ranch Reserve & BORR & 1,327 & Research Reserve \\
\hline Joseph Grant County Park & JGCP & 4404 & Public Recreation \\
\hline San Felipe Ranch & SFR & 11,477 & Cattle Grazing \\
\hline Henry Coe State Park & HCSP & 35208 & Public Recreation, Cattle Grazing \\
\hline & Total & 53,127 & \\
\hline
\end{tabular}

Past ranching activities and subsistence farming dominated the landscape of the Diablo Range, which led to the creation of dams to be used as seasonal and permanent livestock ponds. Stock ponds were created along seasonal waterways, creeks and streams. Although the exact number of stock ponds is unknown, many hundreds were built in Santa Clara County. Cattle were once ranched at all five properties, but now they are grazed only at JGCP and SFR (Table 1). Only HCSP and JGCP are open to the public for recreation activities such as camping, fishing, biking, hiking, and horseback riding. 
The study sites support a range of habitats that include a mosaic of oak woodlands, riparian forests, chaparral, wildflower field, and grassland. Many seasonal and perennial streams and ponds support native wildlife, such as California tiger salamander, redlegged frogs, garter snake, rainbow trout/steelhead (Oncorhynchus mykiss), and WPTs (Blue Oak Ranch Reserve, 2018a). Other wildlife typically found in the area include badger (Taxidea taxus), golden eagle (Aquila chrysaetos), reintroduced Tule elk (Cervus elaphus nannodes), mountain lions (Felis concolor), bobcats (Lynx rufus), coyotes (Canis latrans), black-tailed deer (Odocoileus hemionus columbianus), and foxes (Vulpes spp.) (Blue Oak Ranch Reserve, 2018a).

Western ponds turtles are found on all five study site properties. At RCDP, three out of 10 ponds/lakes had documented WPT occurrences (N. Jassal, personal communication, May 5, 2017) while BORR had five ponds and one lake with WPT (Blue Oak Ranch Reserve, 2018b). Surveys for western pond turtle occurrence at JGCP were incomplete but three ponds and one lake were documented in the California Department of Fish and Wildlife (CDFW) California Natural Diversity Database (CNDDB, 2017). Only three ponds/lakes are known to have had WPT at SFR (H. Wittkopp, personal communication, June 17, 2017) plus one record from a different lake on the property (CNDDB, 2017). A limited number of ponds at HCSP were surveyed, of which five had WPT records, although, there were more ponds with records in other areas of the Park.

\section{Study Design}

To determine the extent of WPT occupancy of stock ponds, one turtle survey was conducted at each pond in the study site so that as many ponds could be surveyed as 
possible. Three turtle surveys were conducted on a subset of ponds to better confirm presence/absence of WPT at each stock pond and data on habitat features were collected at these ponds.

Based on the literature, which provided information on habitat features preferred by WPTs, I evaluated seven habitat features at livestock ponds:

1. Surface area: larger ponds may offer more diverse microhabitat for WPT and their food source,

2. Pond depth: deeper ponds may offer cooler water temperature and more escape routes from predators or disturbances,

3. Elevation: higher elevation affects the amount of solar radiation, temperature, and rainfall a pond will receive,

4. Number of basking structures: more basking structures offer turtles more areas to thermoregulate and hide,

5. Presence of bullfrogs: bullfrogs predate on hatchling and small size WPT and may potentially outcompete WPT for local food source,

6. Level of aquatic vegetation: more aquatic vegetation generally means more aquatic insect for WPT to prey on and more places for WPT to hide, and

7. Level of terrestrial tree and shrub cover: the amount of tree and shrub cover can affect dispersal routes for migration, nesting, and estivation.

Pond Selection. For the purposes of this study, stock ponds were defined as pools of water that measured less than $100 \mathrm{~m}$ at their widest points with a dam. Bodies of water longer than $100 \mathrm{~m}$ were considered "lakes" and were excluded from habitat data 
collection. Several lakes were surveyed for WPT due to their proximity to data collection sites. Ponds were identified and located using Google Earth, property maps, California Natural Diversity Database (CNDDB, 2017), and discussions with property managers. Ponds that were shallow ( $<0.33 \mathrm{~m}$ at capacity) and/or less than $10 \mathrm{~m}$ in diameter were included in the overall turtle survey count but excluded from habitat data collection because they were likely to dry up and, for this reason, appeared less likely to support a resident turtle population than larger pools. An image of a livestock pond at JGCP is provided in Figure 2.

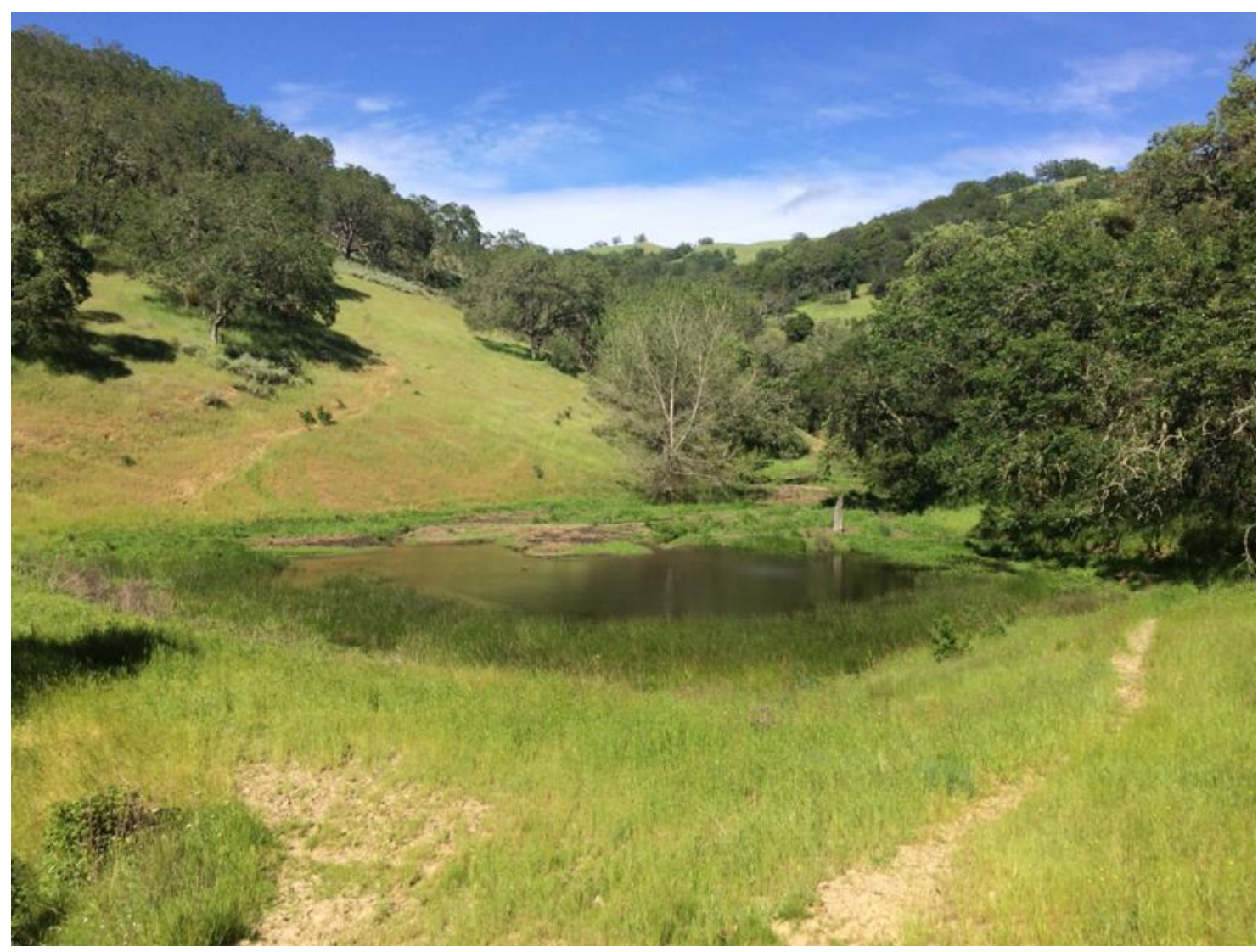

Figure 2. Livestock Pond at Joseph Grant County Park. 
This study was initially limited to BORR, JGCP, and SFR but was later expanded to include selected sites from RCDP and HCSP because of the low number of ponds with WPT in the original site list. Access to the ponds required a combination of hiking, mountain biking, and the use of a four-wheel drive vehicle. Only accessible ponds could be surveyed. In addition, more than 20 ponds were inaccessible because of erosion and/or landslides caused by the heavy winter rain. Because of these factors, ponds could not be randomly sampled in this study. Information regarding whether WPT had been seen or not in stock ponds at BORR, RCDP, SFR, and HCSP were obtained from the property managers and CNDDB (2017). Records of WPT occurrence at JGCP was obtained from only CNDDB (2017).

Turtle Surveys. BORR- Methods to determine the presence or absence of WPTs consisted of a combination of three visual encounter surveys (VES) and setting baited crab traps, model Promar TR-303. VES were conducted between the hours of 0900 and 1700 and consisted of three 15-minute scans of the pond, one scan per day, during threeconsecutive-days using 10x50 binoculars. VES methods included scanning the water's edge and surface and areas where turtles would be capable of basking (logs, rocks, bare ground along the water's edge, and amongst aquatic vegetation). The scans were conducted within five meters from the pond's edge. If turtles were not observed after the first 15-minute scan, then the research team, consisting of two individuals, walked along the pond's perimeter, visually looking for evidence of turtles (e.g., dead carcasses, eggs shells or nest). 
If turtles were not observed after this perimeter walk, two traps baited with canned sardines were placed into the ponds. Traps were attached with two one-meter rebar stakes to hold the trap in place, and two large empty plastic bottles were inserted into the traps to act as flotation devices. Bury et al. (2012) recommended this style of trap because of its success in catching WPTs in lentic habitat. The traps were inspected the following day, within 24 hours of being set, following a second 15 -minute scan/perimeter walk on the day following the first perimeter walk. If no turtles were observed or caught in the trap, the trap was left for an additional 24 hours before conducting the third 15minute scan/perimeter walk and 48-hour trap inspection. If no turtles were observed by the third scan or caught after the 48-hour trap inspection, I concluded that no turtles were present at the pond. Figure 3 depicts two WPTs observed during a VES at SFR.

After the BORR survey was completed, the research team obtained information that some ponds in the study areas contained endangered tiger salamander and that additional approval and permitting from government agencies would be required to continue using traps for this study. To prevent further delays in data collection, the methodology was modified to remove the turtle trapping portion from the remainder of the surveys. 


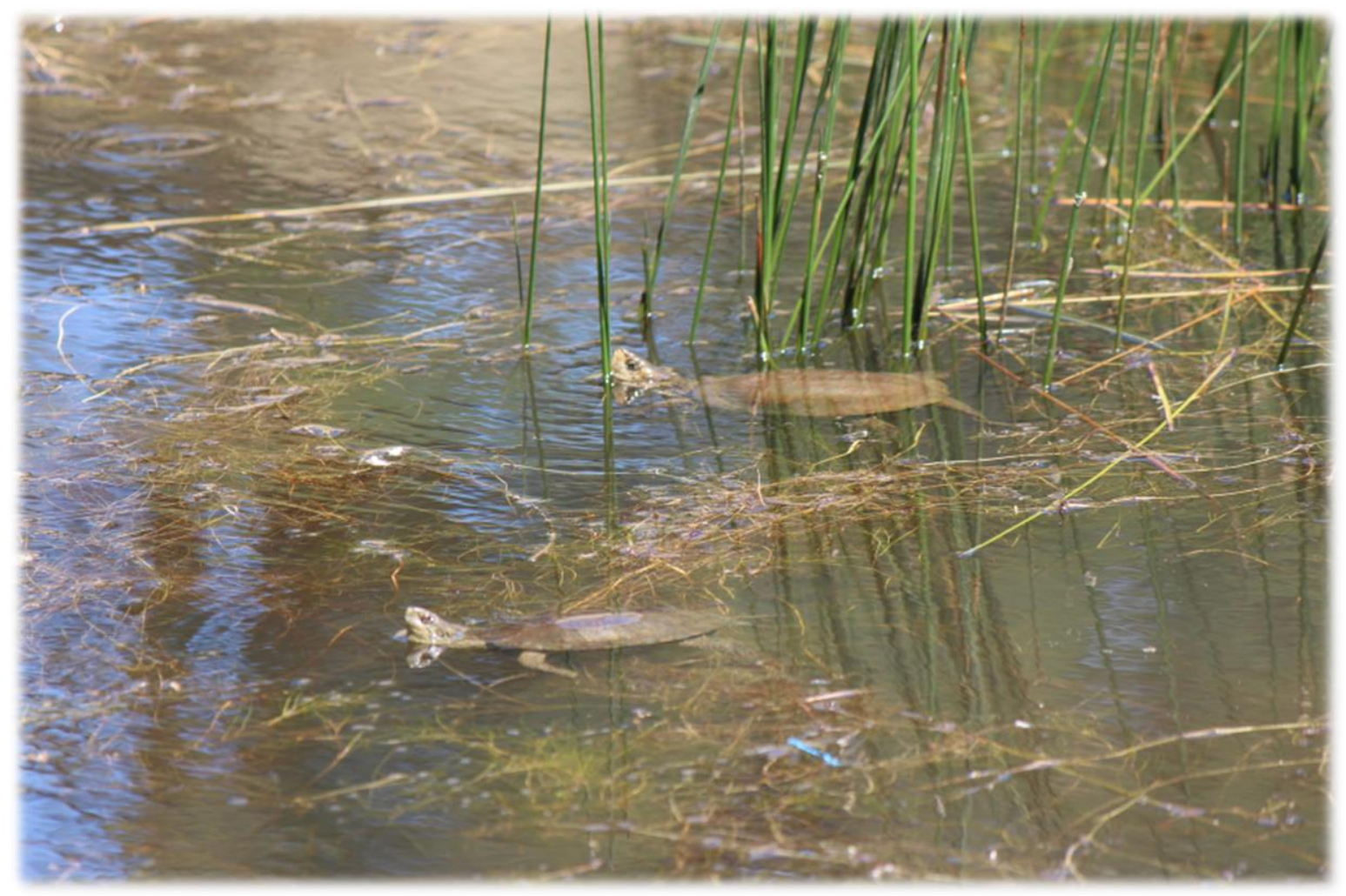

Figure 3. Western Pond Turtles observed at San Felipe Ranch.

At all remaining sites, only the VES, repeated three times, were conducted. At RCDP, the property was surveyed only once and, as a result, did not meet the habitat data collection requirements for this study. Consequently, RCDP was excluded from the habitat analysis but not the survey results.

\section{Data Collection}

Data collection for turtle presence/absence and for habitat characteristics occurred from March 12 to September 17, 2017. Habitat data were collected at ponds with documented turtle occurrence(s) (16 sites) and at other nearby ponds, that were accessible by foot, mountain bike, or four-wheel drive vehicle, to reduce field time and provide adequate safety. 
For each VES, the date, time, weather conditions, and whether turtles were observed was recorded. If turtles were observed, the number of turtles, locations and whether any hatchlings were visible were recorded.

Method(s) for collecting data on the habitat features are as follows:

1. Maximum Surface Area. Pond maximum surface area was determined using the World Imagery Basemap layer in ArcMap (Version 10.6, accessed in May 2018). For each pond, a polygon was created by tracing the perimeter at its widest point, often distinguished by the interface between bare ground, when water level recedes, and green vegetation. When clarity of the pond surface area was blurry or blocked by tree cover, Google Earth Pro was used to triangulate the pond surface area. The calculate geometry function was then used to determine the area of the polygon.

2. Maximum Water Depth. At BORR, maximum water depth was determined using a handheld sonar depth finder (sounder) while kayaking around the pond until the maximum water depth was found. If the pond was shallow, I waded into the pond and used the sounder. Due to an unexpected policy that did not allow access into the ponds at one of the properties, a sonar fishing bobber (Deeper Pro) had to be used. At all other sites, except for one pond at HCSP, the bobber was cast into the pond using a spinning fishing rod and the value was read via Bluetooth through an app on a mobile phone. The maximum depth value was confirmed by recasting the bobber until the maximum depth value was repeated three times. The exception was a pond at HCSP that was filled with dense flotation vegetation which prevented the bobber from obtaining accurate measurements. Therefore, an alternative method to determine the depth value had to be 
used. A rope was tied across the pond with an attached pulley in the middle. The pulley had a second rope with a weighted end. The weighted end was lowered, starting from the ponds surface, until it hit the pond's bottom. The distance lowered was calculated as the maximum depth. This procedure was performed 10 times throughout the middle of the pond until the highest value was determined.

3. Elevation. Elevation was determined using a handheld Garmin GPS (Model GPSMAP 64st).

4. Presence of bullfrogs. Presence of bullfrogs was determined by visually observing the perimeter of the pond using binoculars. Bullfrogs are identifiable based on their extremely large size operculum (circle spot) on each side of the head. Juvenile bullfrogs also make a high pitch chirp before they jump into the water. Bullfrog surveys were conducted concurrently with the WPT survey.

5. Aquatic vegetation cover. Vegetation cover was assessed using the BraunBlanquet cover scale and by classifying the vegetation into three categories: emergent, floating, and submersed. For each pond, the percentage of each vegetation group was scored from one to seven based on percent cover $(1=$ Solitary plant, $2=$ Few $(1-2 \%$ cover), $3=$ Many, but $<5 \%$ cover, $4=5-25 \%$ cover, $5=26-50 \%$ cover, $6=51-75 \%$ cover, $7=>75 \%$ cover). The percentages were then grouped into three categories: low (scale 1-3), medium (scale 4-5), and high (scale >5).

6. Basking Structures. The number of basking structures was determined by visually counting the number of possible basking sites (logs and large rocks). Logs containing multiple large branches were considered one structure. Artificially created basking 
structures, observed at several BORR ponds, were included. A few WPTs were observed basking along banks of the pond. These banks included "bare ground areas" and "areas with short vegetation." As it was difficult to differentiate whether an area along the bank was or was not appropriate for WPT basking, basking "bank areas" were excluded from the number of basking structures.

7. Tree and Shrub Cover. Tree and shrub cover were estimated using the World Imagery Basemap layer in ArcMap (Version 10.6, accessed in May 2018). A 100-meter buffer zone was created around each pond at capacity (Figure 4). For this study, a 100meter from bank buffer zone was chosen because the intent was to focus on the immediate area surrounding each pond and because previous research found, on average, WPTs stay within this proximity to an ephemeral pond (Zaragoza et al., 2015). Within the buffer zone, polygons were created to overlay tree and shrub cover within the buffer zone. Polygons were created in a map scale of 1:1,500 or higher. The "calculate geometry" function was then used to assess the area of the tree and shrub cover polygons. The combined area of the polygons was then divided by the area of the buffer zone to get the percentage tree and shrub cover. The percentages were grouped into three categories: low cover $(0-10 \%)$, medium cover $(10-25 \%)$, and high cover $(>25 \%)$. 


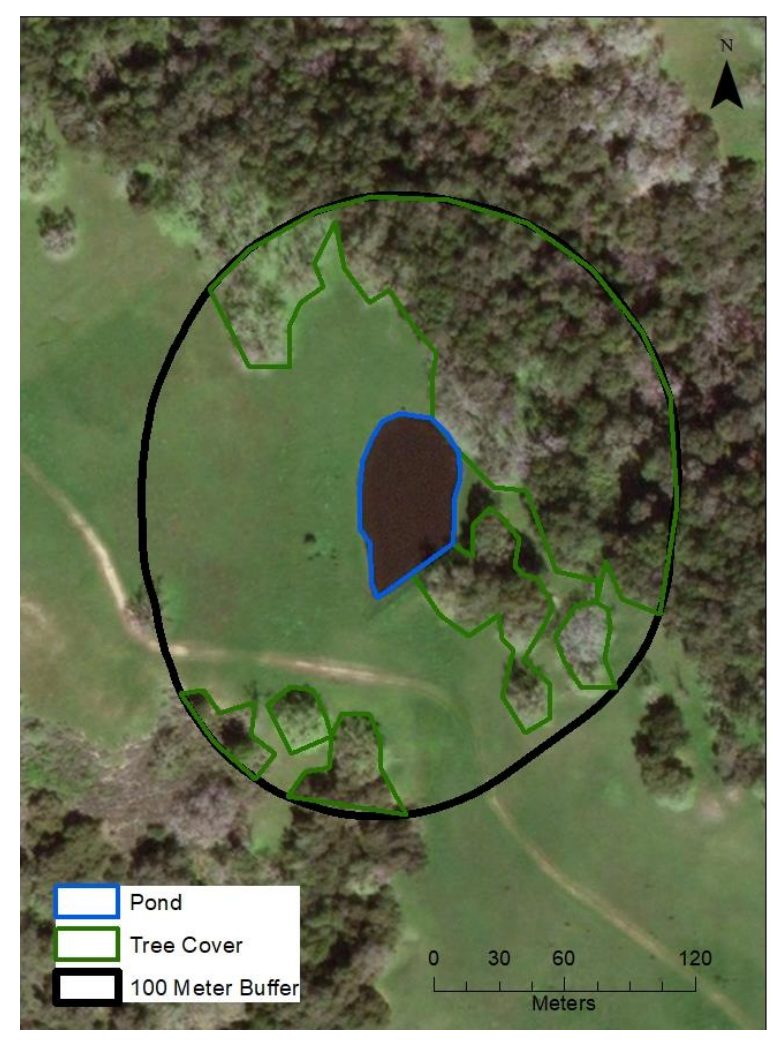

Figure 4. Tree and Shrub Cover Polygon.

\section{Data Analysis}

Descriptive statistics were used to quantify the extent to which stock ponds were occupied by WPT and to compare previously documented occurrences with survey results.

A multivariate analysis of variance (MANOVA) was used to compare ponds with and without turtles in terms of their surface area, maximum water depth, elevation, and number of basking structures. Statistical analysis was conducted using SPSS 24 (IBM Corp 2017). Each variable was tested for normality using the skewness function. When necessary, the data were transformed by $\ln (x+1)$. Data were considered normally 
distributed when skewness was between -2 and 2 . A Pearson correlation was used to test for correlations among the variables. No correlations were greater than 0.70 . However, there was a moderate correlation between $\ln ($ Surface Area +1$)$ and $\ln ($ Depth +1$)(r(29)=$ 0.63, $p<0.01), \ln ($ Depth +1$)$ and basking structure $(r(29)=0.60, p<0.01)$, and basking structure and $\ln ($ Surface Area +1$)(r(29)=0.38, p<0.05)$. The MANOVA $\alpha$ was set at 0.10 due to the small sample size of ponds with WPT.

Prior to running the MANOVA, a Levene's $F$ test was used to test for equality of variance. No variables were significant except for $\ln ($ Surface Area $)(p<0.05)$. A Box's M Test for equality of covariance also was not significant (test statistic $=20.45, p=0.07$ )

A power curve analysis was conducted using SYSTAT 13 (Systat Software, Inc., 2017) to determine what an appropriate sampling size would be to confidently detect a difference. The habitat variable with the lowest MANOVA p-value was used for the power curve analysis.

To evaluate whether the presence of bullfrogs, aquatic vegetation cover (emergent and submersed), or tree and shrub cover affected WPT occupancy of ponds, Chi-square analysis was used $(\alpha=0.10)$. Floating vegetation was not analyzed because duckweed blooms were observed and would likely impact the analysis. A p-value of 0.10 or less would indicate a significant difference between the habitat variables and WPT presence in stock pond.

\section{Limitations}

This study was limited to ponds within the Diablo Range of Santa Clara County and may not be generalized to other geographic areas. Turtles are cryptic and difficult to find 
with just visual encounter surveys. Nevertheless, the goal was to determine the extent of stock pond occupancy by visiting as many ponds as possible, and an exact presence/absence conclusion was not necessarily required. While turtles may have been present at some ponds where I did not observe them, repeating VES three times helped reduce false negatives in the study comparing habitat features between ponds with and without WPT. There may also have been some bias towards detecting WPT at sites with more basking structures, as our primary method for WPT detection was VES.

In addition, California experienced a severe drought from 2012 to 2015 followed by a wet winter in 2016-2017. The impacts of these conditions on turtle presence/absence are unknown. 


\section{Results}

A total of 78 ponds were surveyed for WPT, at least once (Table 2). VES repeated three times and habitat data were collected from 31 ponds out of the 78 surveyed (Table 2, Figure $5 \& 6$ ). Of the 78 ponds surveyed, WPT were present in 13 ponds (17\%). Interestingly, 12 of the 13 occupied ponds were previously documented to have WPT within the last 15 years. Of the 31 ponds where habitat data were collected, turtles were observed in 13 ponds (Table 2).

Table 2.

Ponds Surveyed and Data Collection Sites.

\begin{tabular}{|c|c|c|c|c|}
\hline \multirow[b]{2}{*}{ Survey Site } & \multirow[b]{2}{*}{$\begin{array}{c}\text { Ponds } \\
\text { Surveyed }\end{array}$} & \multirow{2}{*}{$\begin{array}{c}\text { Ponds } \\
\text { Surveyed } \\
\text { with } \\
\text { Documented } \\
\text { Occurrence }\end{array}$} & \multicolumn{2}{|c|}{ Data Collection Sites } \\
\hline & & & $\begin{array}{l}\text { Ponds with WPT } \\
\text { Observed }\end{array}$ & $\begin{array}{c}\text { Ponds } \\
\text { without } \\
\text { WPT }\end{array}$ \\
\hline Rancho Canada de Pala & 6 & $2^{*}$ & 0 & 0 \\
\hline Blue Oak Ranch Reserve & 15 & 5 & 5 & 7 \\
\hline Joseph Grant County Park & 26 & 3 & 2 & $5+1 *$ \\
\hline San Felipe Ranch & 23 & 1 & $1+1 * *$ & 3 \\
\hline Henry Coe State Park & 8 & 5 & 4 & $1+1 *$ \\
\hline Total & 78 & 16 & 13 & 18 \\
\hline
\end{tabular}

WPTs were previously documented in 16 of the 31 habitat-data collected ponds and turtles were present in 12 of these (75\%), minus a newly discovered site. The four ponds that previously had records of WPT, but none were observed were at: RDCP (2), JGCP (1), HCSP (1). No WPT was observed at RCDP using single day surveys. One RCDP pond contained two other turtle species: one red-ear slider (Trachemys scripta elegans) 
and one unknown species. The pond at JGCP had one documented WPT in 2012 (record provided by CDFW from the Herpetological Education \& Research Project) and the habitat appeared to be potential WPT habitat, with lots of aquatic vegetation and some basking spots. However, I did not observe any WPT during our three survey days and suspect that the population may have been small, as only one was ever documented; or, it is also possible that the turtle was using the pond as a migration corridor because the closest population is over $3 \mathrm{~km}$ away. The last pond surveyed at HCSP had some dam failures in years back (S. Ferry, personal communication, May 15, 2017), resulting in a loss of water storage capacity, which likely forced the turtles to leave the site. Consequently, it appears that of the four ponds, only the two at RCDP are likely to still be extant.

Of the 62 ponds where there were no previous records of WPT (Table 3), only one showed evidence of WPT, a recently rehabilitated pond (2012) at San Felipe Ranch.

Table 3.

Previously Documented Occurrence vs. Survey Results (78 Total Ponds).

\begin{tabular}{|c|c|c|c|c|}
\hline \multicolumn{2}{|c|}{} & \multicolumn{3}{|c|}{ Previously Documented } \\
\cline { 3 - 5 } \multicolumn{2}{|c|}{} & Yes & No & Total \\
\hline \multirow{3}{*}{$\begin{array}{c}\text { Presence } \\
\text { Confirmed }\end{array}$} & Yes & 12 & 1 & 13 \\
\cline { 2 - 5 } & No & 4 & 61 & 65 \\
\cline { 2 - 5 } & Total & 16 & 62 & 78 \\
\hline
\end{tabular}

Although VES were conducted three times at 31 ponds to try to ensure adequate observation, when turtles were detected, they were found on the first survey. Thus, one survey seemed to have been adequate to ensure detections. So, although only one VES 
was conducted at most of the ponds, this level of surveying was likely to have been sufficient to detect WPT at these study sites.

Six ponds had more than 10 WPT observed: BORR (2), HCSP (3), and SFR (1). Hatchlings were observed at three ponds, two in BORR and one at HCSP.

In addition to ponds, five lakes where WPT were documented in the past were also visited, and four still had WPT (Table 4).

\section{Table 4.}

Lakes Surveyed.

\begin{tabular}{|lcc|}
\hline \multicolumn{1}{|c}{ Survey Site } & $\begin{array}{c}\text { Number of Lakes } \\
\text { Surveyed }\end{array}$ & $\begin{array}{c}\text { Number of Lakes with } \\
\text { WPT Observed }\end{array}$ \\
\hline \hline Rancho Canada de Pala & $1^{*}$ & 0 \\
Blue Oak Ranch Reserve & 1 & 1 \\
Joseph Grant County Park & 1 & 1 \\
San Felipe Ranch & 2 & 2 \\
Henry Coe State Park & - & - \\
\hline \hline & 5 & 4 \\
\hline
\end{tabular}

*Lakes with documented turtle occurrence(s) but none observed 


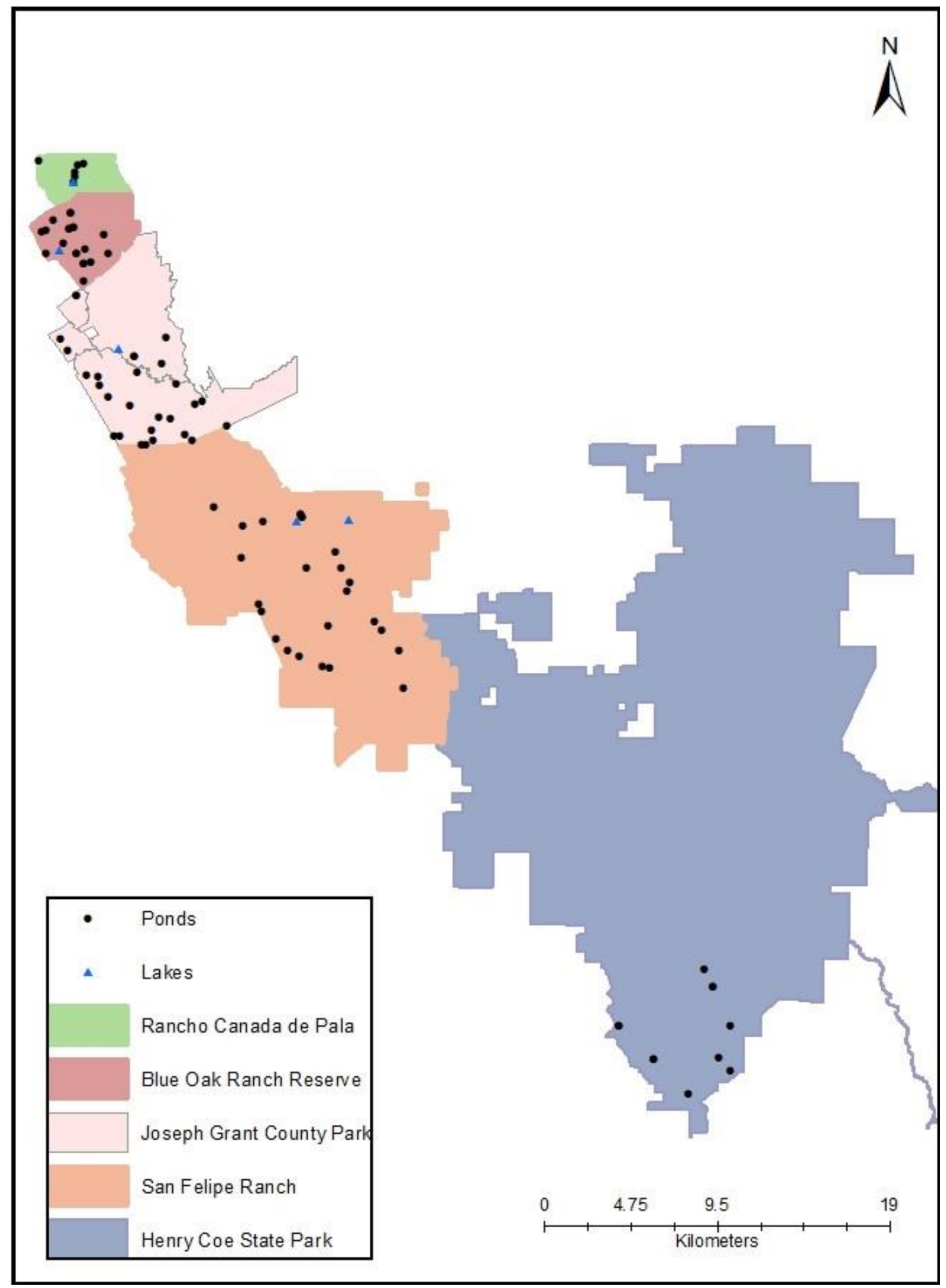

Figure 5. Ponds and Lakes Surveyed. 


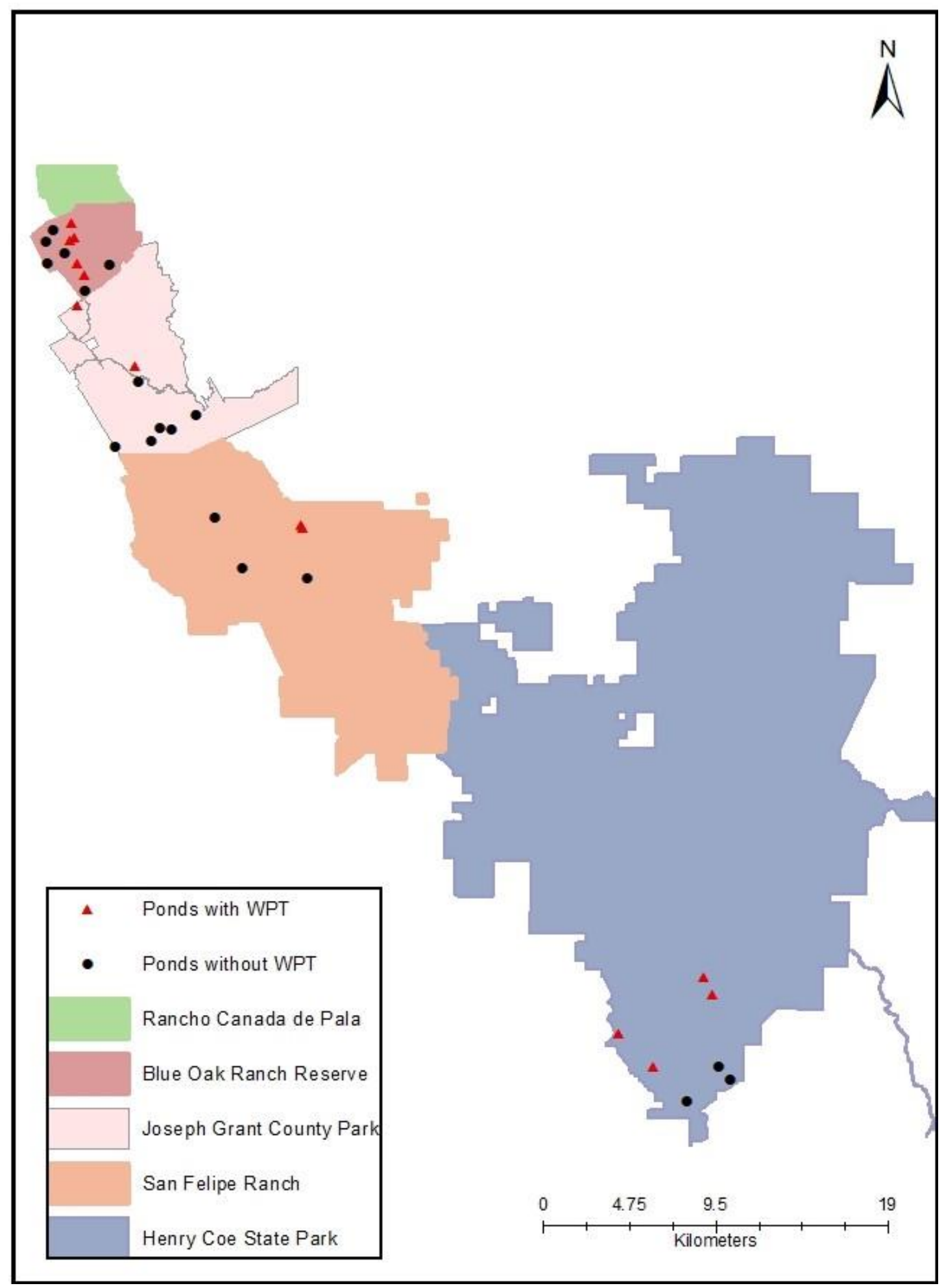

Figure 6. Habitat Data Collection Sites. 
Surface area, water depth, and elevation did not differ between ponds where turtles were present and those where turtles were absent $(p=0.15, p=0.29$, and $p=0.98$, Table 5). The average number of basking structures in ponds with WPT was more than twice that of the number in ponds without WPT (1.38 vs. 0.67) and this difference was significant $(p=0.08$, Table 5). However, the observed power was only 0.41 .

The multivariate effects were not significant (Pillai's Trace $=0.14, F=1.02, d f=4, p$ $=0.42$.

Table 5.

Range, Mean, Standard Deviation (SD) and MANOVA Results for Pond Occupancy (presencelabsence) by Western Pond Turtles.

\begin{tabular}{|c|c|c|c|c|c|c|c|c|}
\hline \multirow[b]{2}{*}{$\begin{array}{l}\text { Habitat } \\
\text { Features }\end{array}$} & \multicolumn{2}{|c|}{$\begin{array}{c}\text { Ponds with } \\
\text { WPT }\end{array}$} & \multicolumn{2}{|c|}{$\begin{array}{c}\text { Ponds without } \\
\text { WPT }\end{array}$} & \multicolumn{4}{|c|}{ MANOVA } \\
\hline & Range & $\begin{array}{l}\text { Mean } \\
\text { (SD) }\end{array}$ & Range & $\begin{array}{l}\text { Mean } \\
\text { (SD) }\end{array}$ & $\boldsymbol{F}$ & $d f$ & $p$ & $\begin{array}{c}\text { Observed } \\
\text { Power }\end{array}$ \\
\hline $\begin{array}{l}\text { Surface Area } \\
\left(\mathrm{m}^{2}\right)\end{array}$ & $\begin{array}{l}6.54- \\
8.41\end{array}$ & $\begin{array}{l}7.48 \\
(0.54)\end{array}$ & $\begin{array}{l}5.20- \\
8.59\end{array}$ & $\begin{array}{l}7.00 \\
(1.09)\end{array}$ & 2.19 & 1 & 0.15 & 0.30 \\
\hline Depth (m) & $\begin{array}{l}0.53- \\
1.93\end{array}$ & $\begin{array}{l}1.21 \\
(0.43)\end{array}$ & $\begin{array}{l}0.53- \\
1.70\end{array}$ & $\begin{array}{l}1.05 \\
(0.37)\end{array}$ & 1.18 & 1 & 0.29 & 0.18 \\
\hline Elevation (m) & $\begin{array}{l}294- \\
824\end{array}$ & $\begin{array}{l}597 \\
(175)\end{array}$ & $\begin{array}{l}337- \\
805\end{array}$ & $\begin{array}{l}599 \\
(120)\end{array}$ & 0.00 & 1 & 0.98 & 0.05 \\
\hline $\begin{array}{l}\text { \# of Basking } \\
\text { Structure }\end{array}$ & $0-3$ & $\begin{array}{l}1.38 \\
(0.96)\end{array}$ & $0-3$ & $\begin{array}{l}0.67 \\
(1.19)\end{array}$ & 3.22 & 1 & 0.08 & 0.41 \\
\hline
\end{tabular}

Note: $\mathrm{n}=31$ for each variable

A power curve analysis on the number of basking structures indicated that a sample size of 39 for each dependent variable group (total sample size 78) would be needed for the power to be 0.80 with an $\alpha$ of 0.05 . 


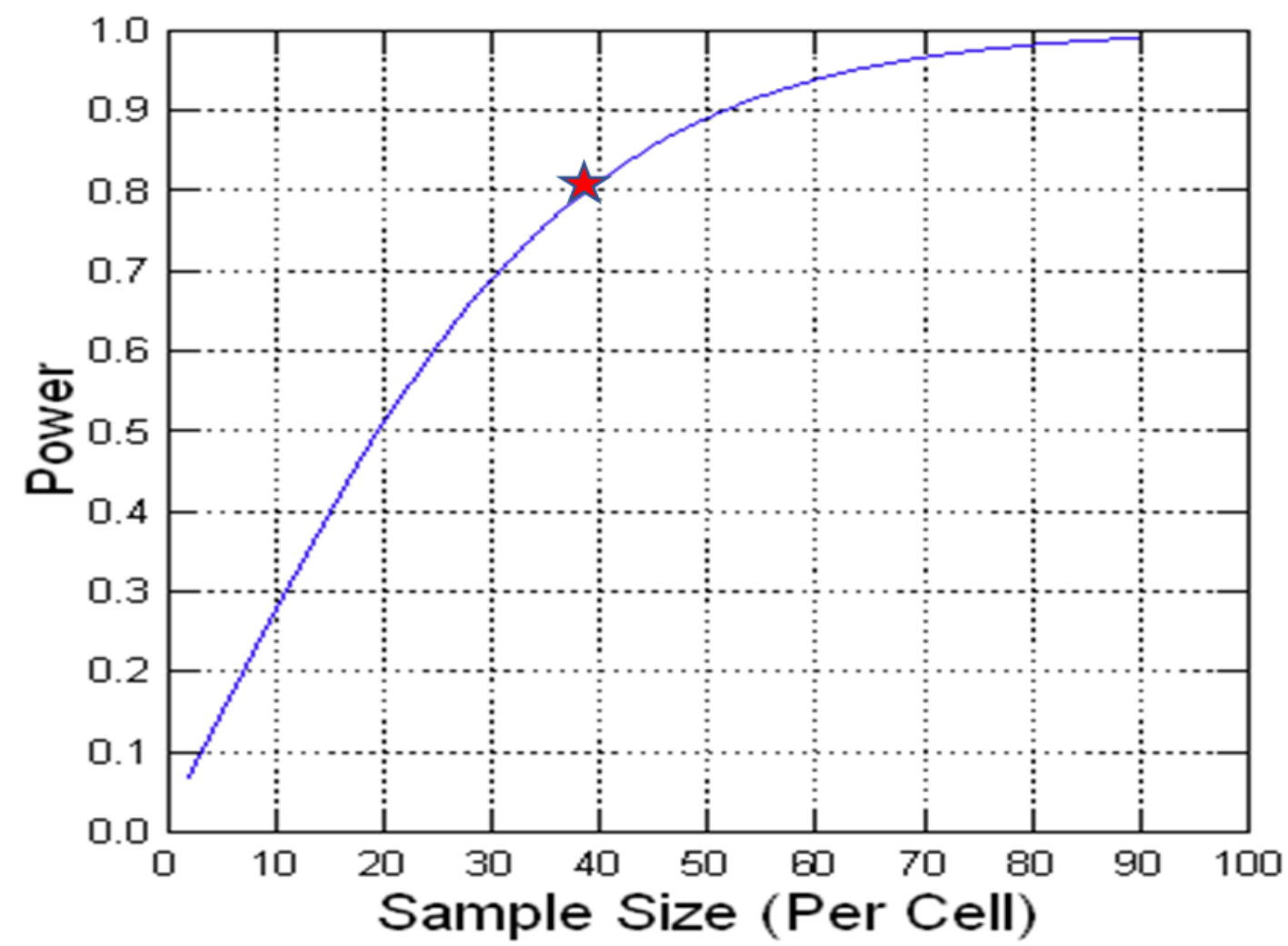

Figure 7. Number of Basking Structures Power Curve Analysis.

For emergent and submersed vegetation, and presence of bullfrog, the Pearson Chisquare analyses showed no relationship with presence/absence of WPTs (Table 6, Figures $8,9, \& 10)$. There was, however, a significant relationship between tree and shrub cover and pond occupancy by WPT ( $p=0.10$, Table 6 , Figure 11). No ponds with WPT had low tree and shrub cover. All four habitat variables had more than $20 \%$ of the expected count cells at less than five, which violated one of the assumptions of the test. However, the likelihood ratio for emergent and submersed vegetation, and presence of bullfrog was not significant ( $p<0.10$, Table 6 ), further supporting the Chi-square results. The likelihood ratio for tree and shrub cover was significant $(p=0.06$, Table 6$)$. 
Table 6.

Pearson Chi-Square Analysis and Likelihood Ratio for Pond Occupancy (presencelabsence) by Western Pond Turtles.

\begin{tabular}{lcccc} 
Model & $\mathrm{X}^{2}$ & df & p value & $\begin{array}{c}\text { Likelihood } \\
\text { Ratio }\end{array}$ \\
\hline Emergent Vegetation (Low, Med, High) & 0.88 & 2 & 0.64 & 0.64 \\
Submersed Vegetation (Low, Med, High) & 0.52 & 2 & 0.77 & 0.77 \\
Presence of Bullfrog (Present, Absent) & 0.09 & 1 & 0.77 & 0.77 \\
Tree / Shrub Cover (Low, Med, High) & 4.60 & 2 & 0.10 & 0.06 \\
\hline
\end{tabular}

Note: $\mathrm{n}=31$ for each variable

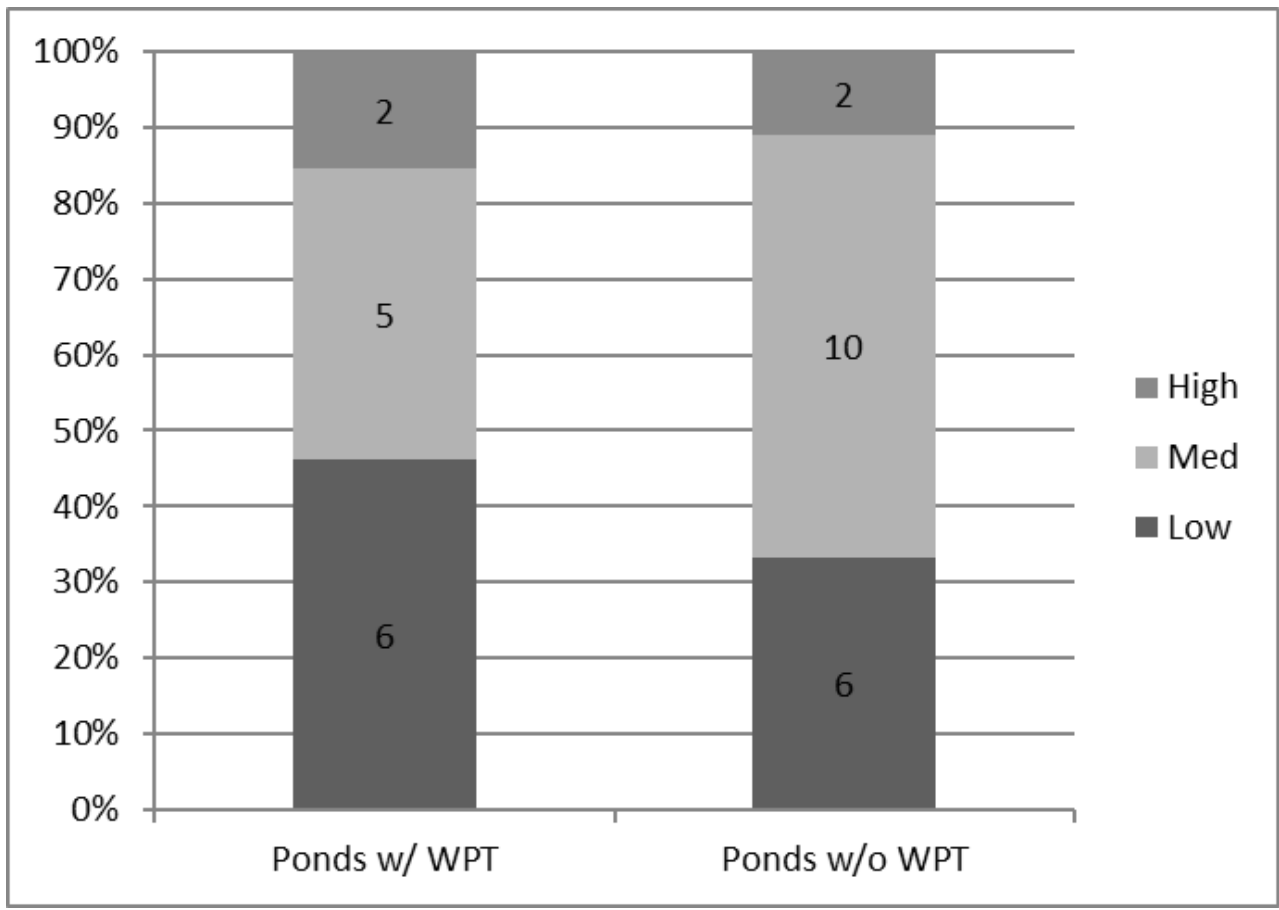

Figure 8. Emergent Vegetation Comparison Between Ponds with and without Western Pond Turtle. Numbers indicate $\mathrm{n}$ in each category. 


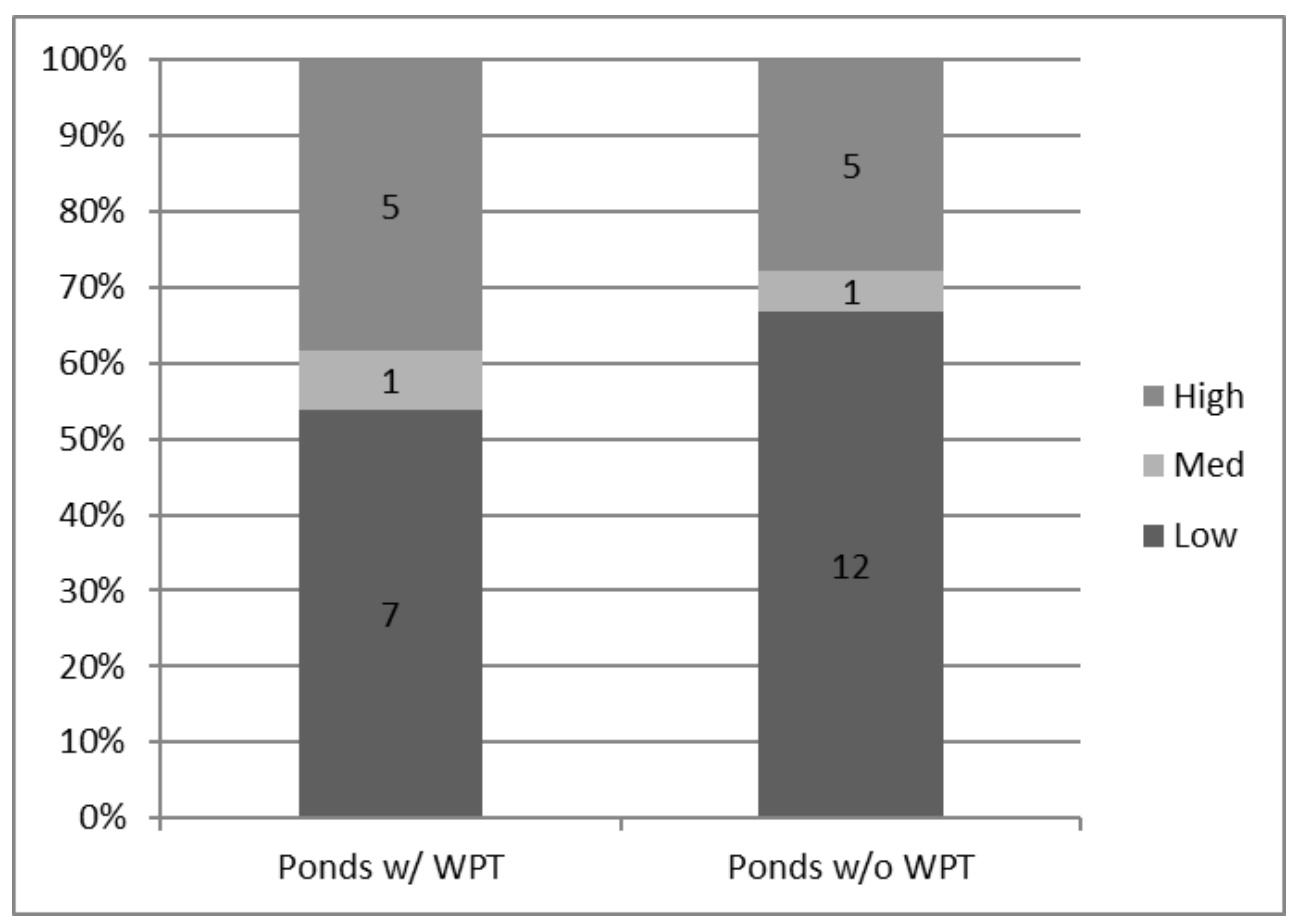

Figure 9. Submersed Vegetation Comparison Between Ponds with and without Western Pond Turtle. Numbers indicate $n$ in each category.

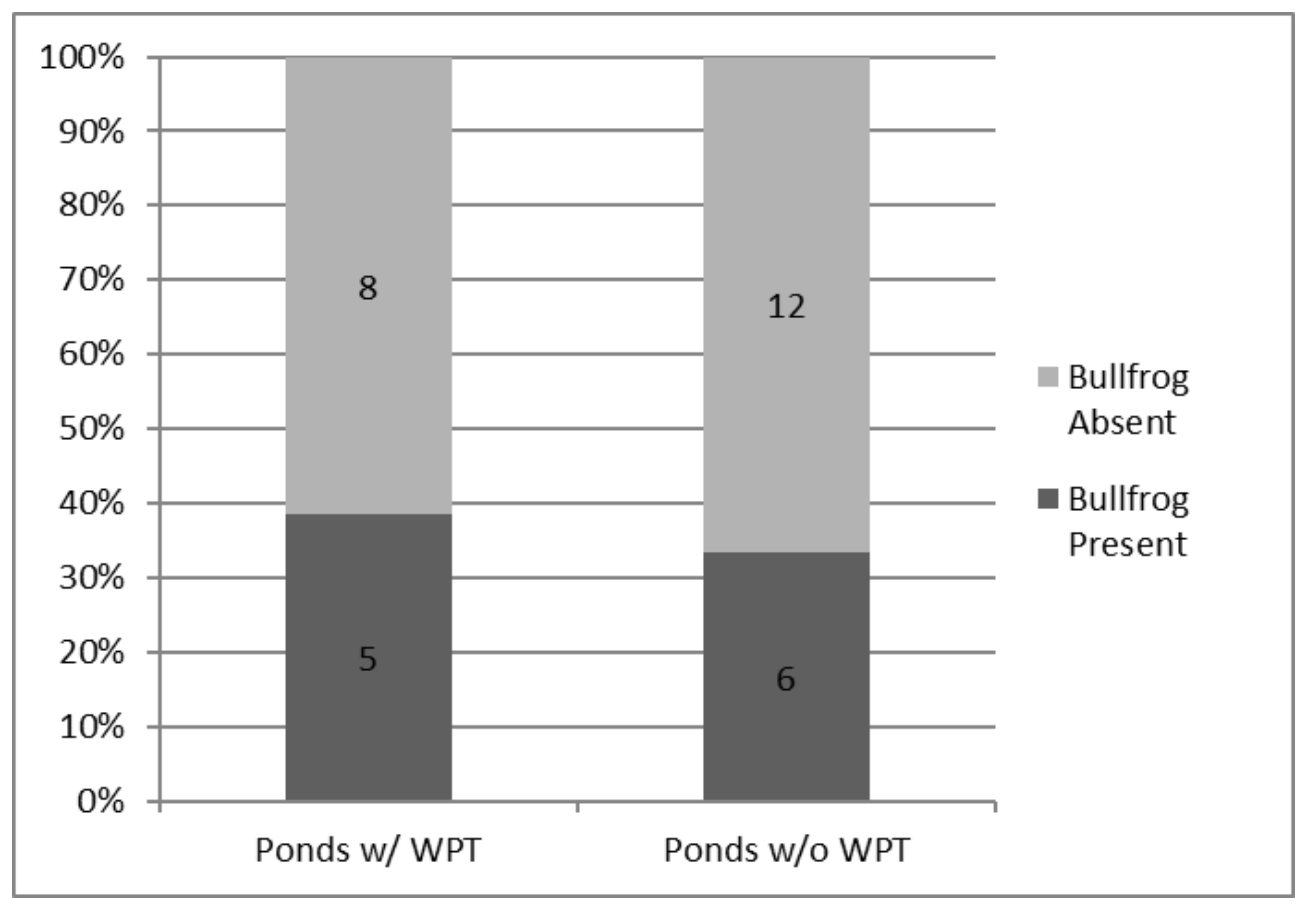

Figure 10. Presence of Bullfrogs Comparison Between Ponds with and without Western Pond Turtle. Numbers indicate $\mathrm{n}$ in each category. 


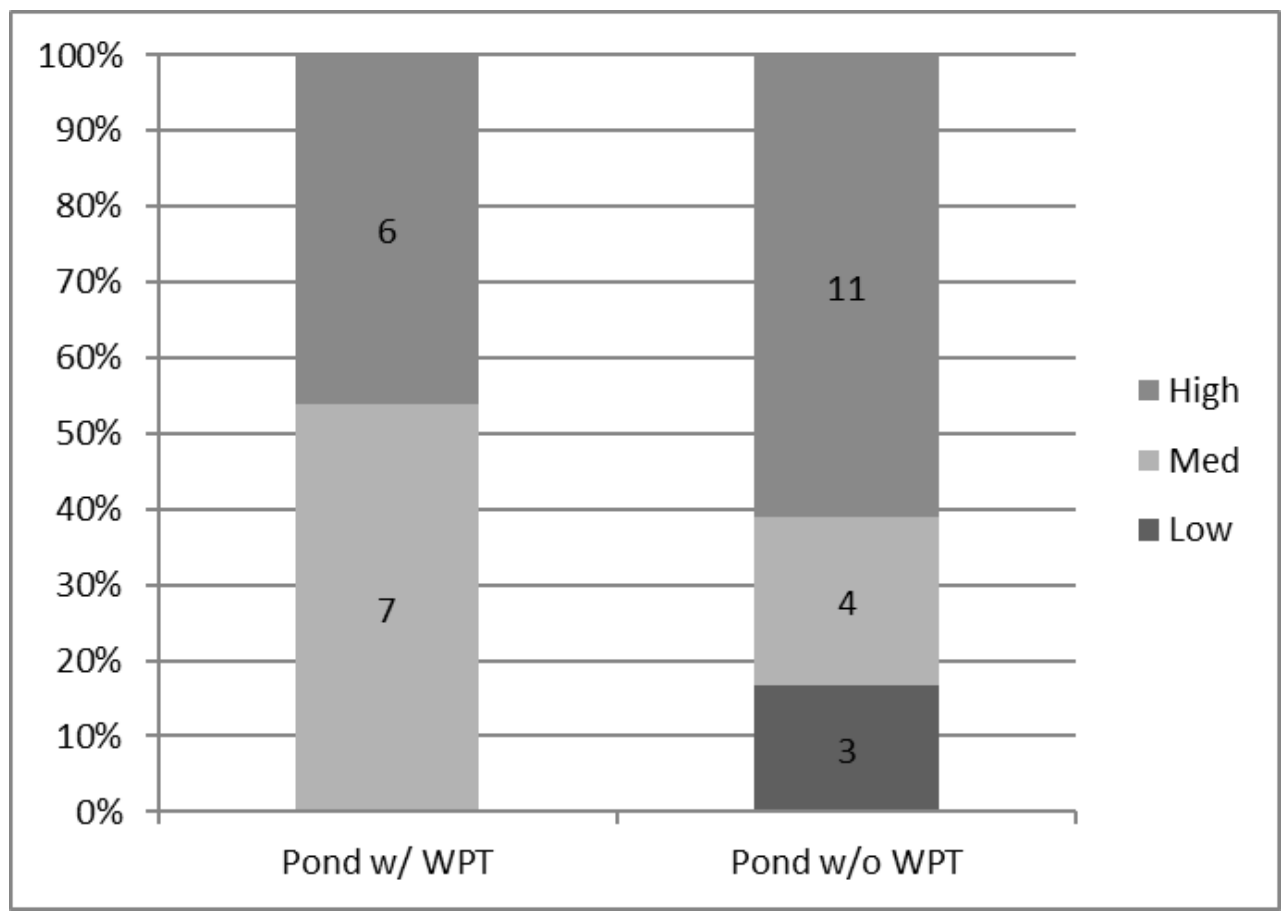

Figure 11. Tree and Shrub Cover Between Ponds with and without Western Pond Turtle. Numbers indicate $n$ in each category. 


\section{Discussion}

\section{Livestock Ponds Usage by Western Pond Turtle}

Livestock ponds have been found to be important habitat for freshwater turtle species including Apalone spinifera, Chrysemys picta, Chelydra serpentina, Kinosternon flavescens, Kinosternon subrubrum, Paracorixa concinna, Sternotherus odoratus, Pseudemys concinna, and Trachemys scripta (Bowne, Bowers, \& Hines, 2006; Failey, McCoy, Price, \& Dorcas, 2007; Stone, Powers, \& Babb, 2005). This study provides baseline information on the extent of livestock pond use by WPT in Santa Clara County, California. While roughly $22 \%$ or 17 of 78 ponds were previously or presently found to contain WPT, this may be an overestimate of overall pond occupancy, as I was not able to sample randomly. A much lower occupancy estimate comes from San Felipe Ranch where only five of the approximately 124 ponds and lakes have ever had WPT observed in them. Although many ponds were not used by WPT, this study showed the great importance of previously-occupied ponds to WPT, as I found turtles still inhabiting 75\% of ponds with previous sightings.

Of particular importance were the six ponds that had >10 WPTs, three of which contained hatchlings. These ponds varied in size with moderate levels of aquatic vegetation (emergent and submersed) and moderate to high numbers of basking structures. The high number of turtles is a positive indicator of food and habitat availability while the presence of hatchlings indicates that reproduction is occurring, and adequate nesting sites are found nearby. In addition, surveys were conducted in the spring of 2017, after the first above normal annual rainfall in the past five years, so turtles 
observed represent persistent populations. These factors indicate that some stock ponds can support self-sustaining WPT populations.

\section{Livestock Ponds and Habitat Features}

Given the small sample size and the range of data, results from this study were inconclusive in assessing habitat features between ponds with and without WPT, but the basic data are consistent with previous studies: basking structures and tree and shrub cover are prevalent and important habitat features in occupied turtle habitat.

Western pond turtles, although somewhat flexible in habitat use, prefer slow moving water with underwater refugia and basking habitat (Bury \& Germano, 2008). This study found a significant difference, at the 0.10 level, in the number of basking structures between occupied and unoccupied ponds. In lotic system, such as, the Trinity River in Northern California, WPT have been found to be associated with basking structures, but this association may be less critical in areas where higher water temperature is available (Reese, 1998). Stock ponds, although they vary in size and shape, are generally considered to be warmer environments than lotic systems because the water no longer flows, thus allowing the water to gradually warm. Warmer water temperatures in stock ponds may contribute to less reliance on basking structures, making them less important in lentic habitat. Another potential factor is the amount of solar radiation available at each pond and the location of basking structures relative to sunlight. Basking structures positioned away from sunlight may be less useful than ones that are directly facing the sun. In the North Umpqua watershed, Oregon, WPT occupancy in ponds increased with more solar radiation (Horn \& Gervais, 2018), but the relationship between solar radiation 
and basking structure placement has not been investigated. Nevertheless, to determine whether the number of basking structures plays a role in stock pond occupancy, a much larger sample size will be needed for future studies.

Studies have shown that some species of turtles prefer larger waterbodies (Attum, Lee, Roe, \& Kingsbury, 2008; Failey, 2007), which may be due, in part, to larger waterbodies offering more diverse microhabitats. However, in this study, no differences in pond surface area were observed. One potential contributing factor is that surface area was limited to no more than $100 \mathrm{~m}$, making it less likely to find a difference when larger ponds $(>100 \mathrm{~m})$ were excluded. During our surveys, four of the five lakes had WPTs suggesting that larger waterbodies are indeed an important habitat characteristic. Along with more diverse habitats, larger ponds typically have deeper water depth. Deeper water offers several advantages including longer water detention time, more escape routes, and cooler water during extreme heat. Yet, no differences in water depth and pond occupancy were observed. Unlike lotic systems, lentic systems have limited lifespans due to natural succession and sedimentation. This in turn causes the pond to lose water depth over time. Depending on the age and the rate of succession, differences in water depth may not have been observed as those factors were not investigated. The rate of succession, which negatively impacts water depth, could influence a turtle's decision to remain at the ponds. Natural plant succession in wetland habitats have been cited as a contributing factor to the decline of bog turtles (Glyptemys muhlenbergii) in the eastern United States (Byer et al., 2017; Melendez et al., 2017). 
Aquatic vegetation cover, submersed and emergent, were not found to be different with WPT occupancy of stock ponds in this study. These results were somewhat surprising given that aquatic vegetation offers several benefits including increasing the number of hiding and basking spots and potentially increasing aquatic invertebrates' abundance and diversity by contributing to more heterogeneous microhabitats. Unfortunately, there are limited empirical studies on the relationship between aquatic vegetation and WPT, particularly within livestock ponds.

In this study, the level of tree and shrub cover differed between occupied and unoccupied ponds at the 0.10 level. These results are consistent with radio telemetry studies of WPT terrestrial movements where turtles are often found hidden under various substrates in shaded areas (Pilliod, Welty, \& Stafford, 2013; Zaragoz et al., 2015), highlighting the importance of available tree and shrub cover nearby. However, these studies were conducted when the turtles' ponds were drying out, forcing the turtles to retreat into terrestrial cover. In ponds that have water year-round, the amount of tree and shrub cover may be less important. No information on whether surveyed ponds dried out was collected, but we speculate that some of the ponds are seasonal, especially during below average rainfall winters, which suggest tree and shrub cover may be an important landscape feature for WPT residing in stock ponds.

The presence of bullfrogs did not appear to impact WPT occupancy, a finding supported by Horn \& Gervais (2018), who found no predictive relationship between bullfrog presence and pond occupancy by WPT in the North Umpqua watershed of Southwestern Oregon. Bullfrogs are capable of only consuming small sized turtles. 
However, most turtles observed in this study were too large for bullfrogs to consume, and bullfrogs may have had a negative effect on hatchlings.

One potentially important feature that was not investigated was the distance of stock ponds relative to other WPT populations, such as those found in nearby rivers, creeks, and other ponds. This factor was not included because there was no data on local turtle populations and access to adjacent properties was not possible. Stock ponds found closer to known WPT populations may be more likely to have WPT because they reduce interwetland distances and increase the likelihood of successful dispersal, thereby extending the home range of the turtle (Fidenci, 2000). Attum et al. (2008) found that distances between neighboring wetlands to be a significant predictor of mid-land painted turtle occurrences and contributed this to the less inclined terrestrial movement behavior of the turtle. However, the same study found that proximity to other wetlands was not a significant predictor for the Blanding's turtle (Emydoidea blandingii), due to it being a vagile species. Horn \& Gervais (2018) found that WPT abundance in rivers increased as distance to nearest ponds and wetland habitat types increased, suggesting that WPTs are more likely to disperse to ponds when they are closer. Whether there is a significant difference between WPT occurrence in stock ponds and distance to the nearest WPT population is unknown. 


\section{Recommendations}

Livestock ponds are high value conservation areas that support many species facing decline due to habitat lost. Although WPT occupancy of livestock ponds in the Diablo Range of Santa Clara County was found to be low, potentially indicating a limited range of pond features which WPT can inhabit, these ponds provide alternative habitats and can increase WPT abundance in the area. Therefore, efforts should be implemented to continually monitor and protect existing turtle-occupied ponds, which showed a high degree of occupancy. Additionally, pond depth should be monitored due to the potential for sedimentation and natural succession. New stock ponds are likely not being created as frequently as they had been in the past due to less grazing, increase environmental regulations and the availability of water and land. Thus, it will increasingly become important to monitor and restore previously occupied ponds to protect WPT.

This study shows a range of pond conditions and habitat features that turtles residing in livestock ponds will use, so an important management tool is to provide more ponds that have these features. Basking structures and tree and shrub cover have been shown in this or other studies to be biologically important. Therefore, increasing the availability of these habitat features may benefit WPT.

Future research on the relationship of occupied ponds to large/source populations will help managers understand where, in the landscape, to locate ponds for monitoring, restoration or creation. Research on the role of ponds as places for turtles to stop as they move to other sites or as sites for self-sustaining source populations is needed. 
Additionally, future surveys for WPT should also be conducted to collect baseline data on the local range of this species, particularly on private land and in creeks, where such information is lacking. A better understanding of WPT occurrence and movements could be achieved by conducting radio-telemetry studies and collecting data on microhabitat characteristics where turtles are found. This information can provide resource managers and biologists with more data when determining how to best protect and restore important habitat features. 


\section{REFERENCES}

Attum, O., Lee, Y. M., Roe, J. H., \& Kingsbury, B. A. (2008). Wetland complexes and upland-wetland linkages: landscape effects on the distribution of rare and common wetland reptiles. Journal of Zoology, 275(3), 245-251.

Barnosky, A. D., Matzke, N., Tomiya, S., Wogan, G. O., Swartz, B., Quental, T. B., ... \& Mersey, B. (2011). Has the Earth's sixth mass extinction already arrived?. Nature, 471(7336), 51-57.

Bay Area Census (2010). Santa Clara County. Retrieved from http://www.bayareacensus.ca.gov/counties/SantaClaraCounty.htm

Blue Oak Ranch Reserve (2018a). Species lists. Retrieved from http://blueoakranch.ucnrs.org/explore/species-lists.html

Blue Oak Ranch Reserve (2018b). Species lists. Retrieved from https://blueoakranch.ucnrs.org/explore/vegetation-and-habitats.html

Bodie, J. R. (2001). Stream and riparian management for freshwater turtles. Journal of Environmental Management, 62(4), 443-455.

Bowne, D., Bowers, M., \& Hines, J. (2006). Connectivity in an Agricultural Landscape as Reflected by Interpond Movements of a Freshwater Turtle. Conservation Biology, 20(3), 780-791.

Bury, R. B. (1972). Habits and home range of the Pacific pond turtle, Clemmys marmorata, in a stream community. (Doctoral dissertation). University of California, Berkeley, Berkeley, California.

Bury, R. B. (1986). Feeding ecology of the turtle, Clemmys marmorata. Journal of Herpetology, 20(4), 515-521.

Bury, R. B., \& Germano, D. J. (2008). Actinemys marmorata (Baird and Girard 1852) western pond turtle, Pacific pond turtle. Conservation biology of freshwater turtles and tortoises: a compilation project of the IUCN/SSC Tortoise and Freshwater Turtle Specialist Group. Chelonian Research Monographs, 5, 001.1001.9 .

Bury, R. B., Germano, D. J., \& Ashton, D. T. (2012). Western Pond Turtle: Biology, Sampling Techniques, Inventory and Monitoring, Conservation and Management. Olympia, WA: The Society for Northwestern Vertebrate Biology.

Buskirk, J. (2002). The western pond turtle, Emys marmorata. Radiata, 11(3), 3-30. 
Byer, N. W., Smith, S. A., \& Seigel, R. A. (2017). Effects of site, year, and estimator choice on home ranges of Bog Turtles (Glyptemys muhlenbergii) in Maryland. Journal of Herpetology, 51(1), 68-72.

Casas, J., Toja, J., Peñalver, J., Juan, P., León, M., Fuentes-Rodríguez, D., . . Elorrieta, S. (2012). Farm Ponds as Potential Complementary Habitats to Natural Wetlands in a Mediterranean Region. Wetlands, 32(1), 161-174.

Ceballos, G., García, A., \& Ehrlich, P. R. (2010). The sixth extinction crisis: loss of animal populations and species. Journal of Cosmology, 8(1821), 31.

Center for Biological Diversity (2012). Petition to list 53 amphibians and reptiles in the United States as threatened or endangered species under the Endangered Species Act. Retrieved from https://www.biologicaldiversity.org/campaigns/amphibian_conservation/pdfs/Me ga_herp_petition_7-9-2012.pdf

California National Diversity Database (CNDDB). (2017). Government Version dated June 2, 2017. Retrieved on July 3, 2017.

Cook, D. \& Martini-Lamb, J. (2004). Distribution and habitat use of Pacific pond turtles in a summer impounded river. Transactions of the Western Section of the Wildlife Society, 40, 84-89.

Declerck, De Bie, Ercken, Hampel, Schrijvers, Van Wichelen, ... Martens. (2006). Ecological characteristics of small farmland ponds: Associations with land use practices at multiple spatial scales. Biological Conservation, 131(4), 523-532.

Dubois, Y., Blouin-Demers, G., Shipley, B., \& Thomas, D. (2009). Thermoregulation and habitat selection in wood turtles Glyptemys insculpta: chasing the sun slowly. Journal of Animal Ecology, 78(5), 1023-1032.

Failey, E. L., McCoy, J. C., Price, S. J., \& Dorcas, M. E. (2007). Ecology of turtles inhabiting golf course and farm ponds in the western Piedmont of North Carolina. Journal of the North Carolina Academy of Science, 123(4), 221-232.

Fidenci, P. (2000). Relationship between cattle grazing and the western pond turtle Clemmys Marmorata populations in Point Reyes National Seashore. (Master's Theses). Retrieved from https://repository.usfca.edu/thes/1036

Feldman, C. R., \& Parham, J. F. (2002). Molecular phylogenetics of emydine turtles: taxonomic revision and the evolution of shell kinesis. Molecular phylogenetics and evolution, 22(3), 388-398. 
Florsheim, J. L., Chin, A., \& Nichols, A. (2013). Effects of multiple small stock-pond dams in a coastal watershed in central California: Implications for removing small dams for restoration. GSA Reviews in Engineering Geology, 21, 149-160. DOI: $10.1130 / 2013.4121(12)$

Geist, N. R., Dallara, Z., \& Gordon, R. (2015). The role of incubation temperature and clutch effects in development and phenotype of head-started Western pond turtles (Emys marmorata). Herpetological Conservation and Biology, 10(1), 489-503.

Germano, D.J., \& Bury, R. B. (2001). Westerm Pond Turtles (Clemmys marmorata) in the Central Valley of California: Status and Population Structure. Transactions of the Western Section of the Wildlife Society, 37, 22-36.

Germano, D. J., \& Rathbun, G. B. (2008). Growth, population structure, and reproduction of Western Pond Turtles (Actinemys marmorata) on the central coast of California. Chelonian Conservation and Biology, 7(2), 188-194.

Hays, D. W., McAllister, K. R., Richardson, S. A., \& Stinson, D. W. (1999).

Washington State recovery plan for the western pond turtle. Washington Department of Fish and Wildlife, Olympia, WA.

Holland, D. C. (1991). A synopsis of the ecology and current status of the western pond turtle (Clemmys marmorata) in 1991. Report to USDI Fish and Wildlife Service, National Ecology Research Center, San Simeon, California.

Holland, D. C. (1994). The western pond turtle: habitat and history. Final Report (No. DOE/BP/62137--1). USDOE Bonneville Power Administration.

Horn, R. B., \& Gervais, J. A. (2018). Landscape influence on the local distribution of western pond turtles. Ecosphere, 9(7), 1-19.

H.T. Harvey \& Associates (1999). Western Pond Turtle Distribution and Status-1999. Project \# 1563-01. San Jose, CA. Prepared for the Santa Clara Valley Water District.

H.T. Harvey \& Associates (2012). Santa Clara Valley Water District Western Pond Turtle Site Assessments and Surveys at Selected Santa Clara County Locations. Project \# 3270-07. Los Gatos, CA. Prepared for the Santa Clara Valley Water District.

Jennings, M. R., \& Hayes, M. P. (1994). Amphibian and reptile species of special concern in California (p. 255). Rancho Cordova: California Department of Fish and Game, Inland Fisheries Division. 
Knutson, M., Richardson, W., Reineke, D., Gray, B., Parmelee, J., \& Weick, S. (2004). Agricultural ponds support amphibian populations. Ecological Applications, 14(3), 669-684.

Lambert, M. R., Nielsen, S. N., Wright, A. N., Thomson, R. C., \& Shaffer, H. B. (2013). Habitat features determine the basking distribution of introduced red-eared sliders and native western pond turtles. Chelonian Conservation and Biology, 12(1), 192199.

Leidy, R. A., Bogan, M. T., Neuhaus, L., Rosetti, L., \& Carlson, S. M. (2016). Summer die-off of western pond turtle (Actinemys marmorata) along an intermittent coast range stream in central California. The Southwestern Naturalist, 61(1), 71-74.

Lovich, J. E., \& de Gouvenain, R. C. (1998). Salt cedar invasion in desert wetlands of the southwestern United States: ecological and political implications. Proceedings California Exotic Pest Council, 4, 45-55.

Lovich, J., \& Meyer, K. (2002). The western pond turtle (Clemmys marmorata) in the Mojave River, California, USA: highly adapted survivor or tenuous relict?. Journal of Zoology, 256(4), 537-545.

Melendez, N. A., Zarate, B., Fingerut, J. \& McRobert, S.P (2017). Diet of Bog Turtles (Glyptemys muhlenbergii) from Northern and Southern New Jersey, USA. Herpetological Conservation and Biology, 12, 272-278.

Nyhof, P. E., \& Trulio, L. (2015). Basking Western pond turtle response to recreational trail use in urban California. Chelonian Conservation and Biology, 14(2), 182184.

Pilliod, D. S., Welty, J. L., \& Stafford, R. (2013). Terrestrial movement patterns of western pond turtles (Actinemys marmorata) in central California. Herpetological Conservation and Biology, 8(1), 207-221.

Pires, M. N. (2001). Allocation of reproductive output in the western pond turtle (Clemmys marmorata) in southern California. (Master's Thesis). California State Polytechnic University, Pomona, Pomona, California.

Poff, N., \& Hart, D. (2002). How Dams Vary and Why It Matters for the Emerging Science of Dam Removal: An ecological classification of dams is needed to characterize how the tremendous variation in the size, operational mode, age, and number of dams in a river basin influences the potential for restoring regulated rivers via dam removal. BioScience, 52(8), 659-668. 
Rathbun, G. B., Siepel, N., \& Holland, D. (1992). Nesting behavior and movements of western pond turtles, Clemmys marmorata. The Southwestern Naturalist, 37(3), 319-324.

Rathbun, G. B., Scott Jr, N. J., \& Murphey, T. G. (2002). Terrestrial habitat use by Pacific pond turtles in a Mediterranean climate. The Southwestern Naturalist, 47(2), 225-235.

Reese, D. A. (1996). Comparative demography and habitat use of western pond turtles in northern California: the effects of damming and related alterations. (Doctoral dissertation). Retrieved from https://pdfs.semanticscholar.org/d3f8/018d456c73117aec78f64e78f2c30bc3d842. pdf

Reese, D. A., \& Welsh, H. H. (1997). Use of terrestrial habitat by western pond turtles (Clemmys marmorata): implications for management. In Pages 352-357 in Proceedings: Conservation, Restoration, and Management of Turtles and Tortoises. An International Conference. New York Turtle and Tortoise Society.

Reese, D. A., \& Welsh Jr, H. H. (1998). Habitat use by western pond turtles in the Trinity River, California. The Journal of Wildlife Management, 62(3), 842-853.

Ruggiero, A., Céréghino, R., Figuerola, J., Marty, P., \& Angélibert, S. (2008). Farm ponds make a contribution to the biodiversity of aquatic insects in a French agricultural landscape. Comptes Rendus - Biologies, 331(4), 298-308.

Seeliger, L. M. (1945). Variation in the Pacific mud turtle. Copeia, 1945, 150-159.

Spinks, P. Q., Pauly, G. B., Crayon, J. J., \& Shaffer, H. B. (2003). Survival of the western pond turtle (Emys marmorata) in an urban California environment. Biological Conservation, 113(2), 257-267.

Spinks, P. Q., \& Shaffer, H. B. (2005). Range-wide molecular analysis of the western pond turtle (Emys marmorata): cryptic variation, isolation by distance, and their conservation implications. Molecular Ecology, 14(7), 2047-2064.

Spinks, P. Q., Thomson, R. C., \& Shaffer, H. B. (2014). The advantages of going large: genome-wide SNP s clarify the complex population history and systematics of the threatened western pond turtle. Molecular Ecology, 23(9), 2228-2241.

Stone, P. A., Powers, S. M., \& Babb, M. E. (2005). Freshwater turtle assemblages in central Oklahoma farm ponds. The Southwestern Naturalist, 50(2), 166-171. 
The Nature Conservancy (2018). California, Mount Hamilton. https://www.nature.org/ourinitiatives/regions/northamerica/unitedstates/california/ placesweprotect/mount-hamilton-1.xml

Turtle Conservation Coalition (2011). Turtles in Trouble: The World's 25+ Most Endangered Tortoises and Freshwater Turtles-2011. Lunenburg, MA: IUCN/SSC Tortoise and Freshwater Turtle Specialist Group, Turtle Conservation Fund, Turtle Survival Alliance, Turtle Conservancy, Chelonian Research Foundation, Conservation International. Wildlife Conservation Society, and San Diego Zoo Global, 54 pp.

Turtle Conservation Coalition (2018). Turtles in Trouble: The World's 25+ Most Endangered Tortoises and Freshwater Turtles_-2018. Ojai, CA: IUCN SSC Tortoise and Freshwater Turtle Specialist Group, Turtle Conservancy, Turtle Survival Alliance, Turtle Conservation Fund, Chelonian Research Foundation, Conservation International, Wildlife Conservation Society, and Global Wildlife Conservation. 80 pp.

Usio, N., Imada, M., Nakagawa, M., Akasaka, M., \& Takamura, N. (2013). Effects of pond draining on biodiversity and water quality of farm ponds. Conservation Biology, 27(6), 1429-1438.

Wake, D. B., \& Vredenburg, V. T. (2008). Are we in the midst of the sixth mass extinction? A view from the world of amphibians. Proceedings of the National Academy of Sciences. 105(1), $11466-11473$.

Wilcox, J. T. (2010). Actinemys (= emys) marmorata (Western Pond Turtle) predation. Herpetological Review, 41(2), 212.

Western Regional Climate Center (2016). Mt. Hamilton, California, Period of record monthly climate summary. Retrieved from https://wrcc.dri.edu/cgibin/cliMAIN.pl?ca5933

Zaragoza, G., Rose, J. P., Purcell, K., \& Todd, B. D. (2015). Terrestrial habitat use by western pond turtles (Actinemys marmorata) in the Sierra foothills. Journal of Herpetology, 49(3), 437-441. 